\title{
Uluslararası PISA Yeterlikleri ve Türkiye Öğretim Programları Kazanımları*
}

\author{
International PISA Competencies and the Curriculum \\ Outcomes in Turkey
}

\begin{abstract}
Alaettin İșERI**
Öz: Araştırma Türkiye'deki ortaöğretim öğretim programları kazanımlarının, PISA araştırmaları yeterlik düzeylerine dağılımı durumu ile Türkiye'nin farklı dönemlerdeki PISA performansıyla karşılaştırmasını kapsamaktadır. Araştırma literatür taramasına dayalı nitel bir çalışma olup, durum çalışmasına dayalı yürütülmüştür. Araştırma verileri, Türkiye'de iki farklı dönemde geliştirilen ve PISA araştırmaları kapsamıyla doğrudan ilişkili ortaöğretim, dokuzuncu sınıf fen bilimleri, matematik ve edebiyat dersleri öğretim programlarından seçilen ikişer ünitedeki kazanımları, buna bağlı olarak PISA yeterlik düzeyleri ve farklı dönemlerdeki Türkiye'nin PISA araştırmaları performansı verilerini içermektedir. Araştırma bulguları, ortaöğretim, dokuzuncu sınıf fen bilimleri, matematik ve edebiyat dersleri öğretim programları kazanımlarının, ilk aşamada bilgi türü ve bilişsel nitelikler açısından içerik analizleri ve söylem okumaları bulguları sunulmuştur. Sonraki aşamada ise kazanımların, bilgi içeriği ve bilişsel nitelikler boyutunda yoğunlaştıkları PISA yeterlik düzeyleri ve Türkiye’nin farklı dönemlerdeki PISA araştırmaları performansıyla ilişkisel karşılaştırma verileri sunularak farklı boyutlarda tartışılmıştır.

Anahtar Kelimeler: PISA yeterlikleri, Türkiye öğretim programları
\end{abstract}

\begin{abstract}
The research involves the comparison of learning outcomes of secondary education curriculum in Turkey with the distribution status to the levels of competence of PISA researches and the PISA performance of Turkey in different periods. The research is a qualitative study based on literature review and had been carried out based on a case study. Research data includes the learning outcomes in two units selected from each curricula of secondary education ninth class sciences, math and literature classes developed in two different periods in Turkey and directly related to the scope of PISA researches, accordingly PISA levels of competence, and the data of PISA researches performance of Turkey in different periods. In research findings, the findings on the content analysis and discourse readings of the learning outcomes of the curricula of secondary education ninth grade science, math and literature classes with regards to the information structure and cognitive qualities in the first phase are presented. In next phase, the levels of PISA competence that the learning outcomes concentrate in terms of the information structure and cognitive qualities had been discussed in different dimensions presenting relational comparison data by the performance of PISA researches in different periods in Turkey.
\end{abstract}

Keywords: The competencies of PISA, curriculum in Turkey

\section{Giriş}

Dünyadaki ulusal politikaların, yapısal dönüşümünün temel dinamiği, sosyal yaşam pratikleri ve değer sistemlerinin, uluslar üstü normlarda bütünleşmeye yönelik evrimidir. Bu bağlamda ulusal eğitim politikalarının küreselleşme motivasyonuna bakıldığında, Sayıhan (2007), küresel sermaye normlarının, eğitimde liberalleşme politikalarının motivasyon kaynağı olduğunu, 'küresel eğitim reformu' ile küresel piyasanın gerektirdiği bilgi ve becerilere dayalı eğitim ve programın; rekabete dayalı girişimcilik kültürünü, başarı için temel bir uyaran olarak kabul ettiğini, öğrenci başarısını uluslararası program standartlarına bağladığını belirtmektedir. Buna karşın eğitim politikalarının küreselleşmesini, çok kültürlülük ve çok yönlülük bağlamında olumlayan yaklaşımlarda; Benton (2007) küreselleşme politikalarının, dünyadaki engin kültürel çeşitliliğin,

* Bu makalenin bir bölümü 11-14 Mayıs 2017 tarihlerinde Pamukkale Üniversitesi'nde düzenlenen IV. International Eurasian Educational Research Congress'de sözlü bildiri olarak sunulmuștur.

${ }^{* * *}$ Dr. Öğr. Üyesi Kırklareli Üniversitesi, Fen Edebiyat Fakültesi Eğitim Bilimleri Bölümü, Kırklareli-Türkiye, ORCID:0000-0003-3621-7220, e-posta: aiseri.ebb@gmail.com 
pedagoji, program ve sınıflara girmesini olanaklı kıldı̆̆ını, Oktay (2010) ise ulusal sınırların dışında farklı kültür ve coğrafyalarda yaşayabilen çok dilli-kültürlü eğitim anlayışını yarattı̆̆ını belirtir. $\mathrm{Bu}$ durumu bir paradigma dönüşümü olarak gören Hesapçığlu (2010), sanayi toplumunun 'fordist paradigması'ndan bilgi toplumunun 'bilgi ve iletişim teknolojileri paradigması'na geçişte bir "üretim paradigması" dönüşümüyle bilgi toplumu eğitim modelinin ortaya çıktığını belirtir. Bu küresel dönüşümün uluslar üstü kurum ve normları oluşturması durumuna bakıldığında Eurydice (2002) raporunda, bilginin her zamankinden daha hızlı bir biçimde yaratılması, dağıtılması ve kolay erişilir olmasının, bilgiye sahip olma gerekliliğini azalttığı, eğitimde somut gerçeklerin bilgisini öğretmekten ziyade yeterlikler geliştirme eğilimini oluşturduğu belirtilmektedir. Buna bağlı OECD (2009) raporunda, küresel alanda eğitim politikalarının ortak bir öz ve belirli standartlara yöneldiği, eğitim sistemlerinin de bu öz ve standartlara yönelik nitelik ve performansının belirlenmesinde ortak değerlendirme kurumu olarak Programme of International Student Assesment-Uluslararası Öğrenci Değerlendirme Programı (PISA)'ın ortaya çıtı̆̆̆ belirtilmektedir.

Küresel eğitim politikaları performansını belirlemeye yönelik OECD tarafindan 2000 yılından itibaren yürütülen PISA, OECD'ye üye ve üye olmayan ülkelerin katılımıyla 3 yılda bir, 15 yaş grubundaki öğrencilerin, katılımını içeren geniş ölçekli bir sınav uygulamasıdır. PISA araştırmaları, öğrencilerin; modern toplumda gerekli temel bilgi ve becerilere ne ölçüde sahip olduklarını belirlemeye yönelik fen, matematik ve okuma alanlarındaki; bilgileri kullanma, yaşama aktarma ve yeni durumlara uyarlama, performans ve becerilerini içermektedir. $\mathrm{Bu}$ kapsamda PISA araştırmaları, dünya ölçeğinde eğitim politikalarının kapsam ve niteliğini etkilemekle birlikte, öğrenci bilgi ve becerilerinin; temel bir profilini oluşturma, demografik, sosyo-ekonomik ve eğitimsel değişkenlerle ilişkisini belirleme, öğrenciler ve okullar düzeyindeki değişim eğilimlerini belirlemeyi içermektedir (Anıl, 2009; Anagün, 2011; MEB, 2013d, 2015, 2016; OECD, 2013a,b). Bu açıdan PISA araştırmaları, dünyadaki eğitimin niteliği, ülkelerin potansiyel insan gücünü yordamada önemli veriler sunmaktadır.

PISA araştırmalarındaki üç alanın içeriğine bakıldığında; fen okuryazarlığı alanı, olguları bilimsel olarak açıklama, bilimsel sorgulama yöntemi tasarlama ve değerlendirme, verileri ve bulguları bilimsel olarak yorumlamayı içeren üç boyuttan oluşmaktadır. Matematik okuryazarlığı alanı, matematiksel düşünme eylemleri ve gerçek yaşam durumları olarak iki boyuttan oluşmaktadır. Okuma alanı ise; metin, okurun metne yaklaşımı ve metnin amacı olarak üç boyuttan oluşmaktadır. Bu üç alanın her birindeki bilgi ve beceriler, 6 yeterlik düzeyinden oluşmaktadır. Üst yeterlik düzeyleri olan 5. ve 6. düzeyler, yorumlama, analiz ve sorgulama gibi üst düzey bilişsel becerileri kapsar iken; temel ve asgari düzeydeki yeterlikleri içeren 2. düzey ise, 21. yüzyılda tüm bireylerin hayata hazır olmaları için sahip olmaları gereken temel becerileri içermektedir. Buna bağlı olarak 2. düzeyin altındaki alt yeterlik düzeyleri de yetersizlik ve başarısızlığı içermektedir (Anıl, 2009; MEB, 2010a,b, 2016; OECD, 2016a; TEDMEM, 2015). Bu kapsamda Türkiye'nin PISA performansına bakılabilir.

Türkiye'nin 2003-2015 arası beş dönemlik PISA araştırmaları sonuçlarına ilişkin genel görünümde, 15 yaş grubundaki öğrencilerin yaklaşık yarısının temel ve alt yeterlik düzeylerine yoğunlaştığı, yüksek ve düşük performanslı öğrenciler arasında önemli başarı farklarının olduğu, Türkiye'deki ortalama bir öğrencinin, OECD ülkelerindeki ortalama bir öğrenciden matematik, okuma ve fen becerilerinde 1-1,5 eğitim yılı geride olduğu sonuçlara yansımaktadır (Dünya Bankası, 2011; OECD, 2009; TEDMEM, 2015). Buna karşına Dünya Bankası (2014) raporuna göre, Türkiye'nin eğitimde, OECD standartları ile olan uçurumun azalmaya başladığı, 2003 yılından itibaren Türkiye'nin ortalama PISA puanlarının, diğer tüm ülkelerden daha hızlı bir şekilde iyileştiği belirtilmektedir. Bu bağlamda Türkiye'nin fen, matematik ve okuma alanında son dört dönemdeki PISA performansı karşılaştırmalı incelenebilir.

Tablo-1'den hareketle Türkiye'nin 2006-2015 y1lları arasındaki dört dönemlik fen, matematik ve okuma alanlarındaki performansına bakıldığında: Fen, matematik ve okuma alanlarında Türkiye'nin 2006 yılı puan ortalaması, 2012 yılına kadar yükselirken, 2015 yılında tüm alanlarda, 2006 yılı puan sınırına düştügü; son dört uygulamada Türkiye'nin fen ve okuma 
alanında hem tüm ülkeler hem de OECD ülkeleri bazında ortalama puanlarının gerisinde olduğu, sadece matematik puan ortalamasının 2012'de tüm ülkeler puan ortalamasını geçtiği belirtilebilir.

Tablo 1.

Türkiye'nin Yı1lara Göre Farklı Alanlardaki PISA Sonuçları

\begin{tabular}{|c|c|c|c|c|c|}
\hline & & 2006 & 2009 & 2012 & 2015 \\
\hline \multirow{4}{*}{ 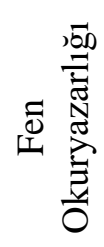 } & Türkiye Ort. & 424 & 454 & 463 & 425 \\
\hline & OECD Ort. & 500 & 495 & 501 & 493 \\
\hline & Tüm Ülke Ort. & 491 & 471 & 477 & 465 \\
\hline & Siralamas1 & $47 / 57$ & $42 / 65$ & $43 / 65$ & $54 / 72$ \\
\hline \multirow{4}{*}{ 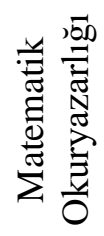 } & Türkiye Ort. & 424 & 464 & 475 & 428 \\
\hline & OECD Ort. & 498 & 493 & 496 & 493 \\
\hline & Tüm Ülke Ort. & 484 & 464 & 471 & 460 \\
\hline & Siralamas1 & $43 / 57$ & $39 / 65$ & $42 / 65$ & $50 / 72$ \\
\hline \multirow{4}{*}{ 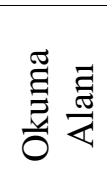 } & Türkiye Ort. & 447 & 445 & 448 & 420 \\
\hline & OECD Ort. & 484 & 496 & 494 & 490 \\
\hline & Tüm Ülke Ort. & 492 & 465 & 470 & 461 \\
\hline & Siralaması & $37 / 56$ & $41 / 65$ & $44 / 65$ & $50 / 72$ \\
\hline
\end{tabular}

Kaynak: OECD, 2016a; OCED, 2013b; MEB, 2010a,b: MEB, 2015; MEB, 2016.

Türkiye'nin küresel ölçekteki PISA performansının, eğitim politikalarına yansımasına bakıldığında: dokuz ve onuncu beș yıllık kalkınma planlarında: eğitimde kalitenin artırılmasına yönelik, yeterlikler, yenilikçilik ve araştırıcılığı içeren programların ülkede yaygınlaştırılması, öğrencilerin bilimsel araştırma ve girişimciliğe teşvik edilmesi ve öğretmen yeterliliklerinin sürekli geliştirilmesi, ulusal ve uluslararası değerlendirme verilerine bağlı olarak her öğrenciye nitelikli bir eğitim sunumu için bölgeler ve okul türleri arasındaki başarı farklılıklarının azaltılması, eğitim programlarının, çağdaş bilgi, beceri ve teknolojileri etkin ve verimli kullanmaya yönelik güncellenmesi ve ulusal yeterlilik çerçevesinin oluşturulması (DPT, 2006, 2013; Kalkınma Bakanlığı, 2014) öngörülmektedir. Buna bağlı olarak Milli Eğitim Bakanlığı'nın gelecek perspektifine ilişkin 2015-2019 stratejik planında, bütün bireylere çağın gerektirdiği bilgi, beceri, tutum ve davranışın kazandırılması ile girişimci, yenilikçi, yaratıcı, dil becerileri yüksek, iletişim ve öğrenmeye açık, özgüven ve sorumluluk sahibi, sağlıklı ve mutlu bireylerin yetişmesi (ERG, 2016) öngörülmektedir.

Küresel ölçekte eğitim politikalarının nitelik ve performansını belirleme aracı olarak PISA araştırmaları, ulusal eğitim politikaları için temel bir başarı kriterine dönüşürken, Türkiye'deki 15 yaş grubu öğrencilerinin küresel yeterlikler bağlamında son beş dönemdeki performansı, eğitimin içerik-niteliğini birçok faktör açısından incelenebilir kılmaktadır. $\mathrm{Bu}$ açıdan, Türkiye'deki öğretim programları, ders kitapları içerikleri, öğretim uygulamalarıiçeriklerinin geliştirilmesi ve değerlendirmesinde rol oynayan temel unsur, mevcut program geliştirme teorisinde öğretim programı ve kazanımlarıdır. Türkiye'de öğretim programları kazanımlarının, bu belirleyici etkisi, kazanımların içerik olarak bilgi yapısı ve bilişsel niteliklerinin, PISA yeterlik düzeyleriyle ilişkisini irdelemeyi gerekli kılmaktadır. Bunun için PISA araştırmaları içeriğiyle doğrudan ilişkili Türkiye ortaöğretim kademesi 9. sınıf fen, matematik ve Türk dili ve edebiyatı dersleri öğretim programları kazanımlarının bilgi türü ve bilişsel nitelikler açısından PISA araştırmaları, fen, matematik ve okuma alanları yeterlik düzeylerine dağılım durumu ve bu dağglım durumunun Türkiye'nin farklı dönemlerdeki PISA performansıyla ilişkisi nedir? Sorusuna araştırmada cevap aranmıştır. Bu sorunun cevabı, Türkiye'deki merkezi öğretim programları ve eğitim politikalarının uluslararası geçerlik niteliklerini belirleme açısından önem taşımaktadır. 


\section{Yöntem}

PISA araştırmaları fen, matematik ve okuma alanları yeterlik düzeyleri kapsamıyla doğrudan ilişkili Türkiye ortaöğretim kademesi dokuzuncu sınıf fen, matematik ve dil bilimleri dersleri öğretim programları kazanımlarının karşılaştırılması, araştırmanın çalışma evrenini oluşturmaktadır. Araştırma, iki farklı eğitim politikasını verilerinin genel-betimsel tarama modelleri kapsamında, resmi rapor, doküman ve belgelere dayalı incelendiği nitel bir çalışmadır (Akturan, 2008; Karasar, 2005; Robson, 2015). Araştırma, aralarında kesin hatların bulunmadığ ve içerik olarak birbiriyle örtüşen iki farklı eğitim politikası olarak; PISA araştırmaları yeterlik düzeyleri ile Türkiye ortaöğretim 9. sınıf öğretim programları kazanımlarının ilişkisel durumuna yönelik birden fazla kanıt ve veri kaynağını, belge ve dokümanlara dayalı, derinliğine incelemede nitel araştırma desenlerinden durum çalışmasına dayalı yürütülmüştür. Durum çalışması kapsamında; tek-bütüncül durum çalışmalarıyla, Türkiye ortaöğretim 9. Sınıf öğretim programları kazanımları ve PISA yeterlik düzeyleri kendi içinde tek bir analiz birimi olarak ayrı ayrı incelenerek daha sonra bütünsel olarak değerlendirilmiştir. İlişkisel durum çalışmasında ise, birbiri ile ilişkili bu iki farklı eğitim politikası verileri karşılaştırmalı olarak değerlendirilmiştir (Akturan, 2008; Baş, 2008; Karasar, 2005; Robson, 2015).

\section{Verilerin toplanması}

Araştırma verilerinin toplanmasında Scott ve Morrison'nun (2016) araştırmalarda belgelerin kanıt niteliğine yönelik belirlediği belgenin; sahiliği, güvenirlik-inandırıcılığı, temsil yeteneği ve anlamı kriterleri esas alınarak; Türkiye ortaöğretim dokuzuncu sınıf öğretim programları kazanımları ve PISA araştırmaları yeterlik düzeylerine ilişkin belge, rapor, dokümanlardan veriler toplanmıştır. Bu kapsamda ilk aşamada 2003-2015 yılları arasındaki PISA araştırmalarının ulusal ve uluslararası raporları karşılaştırmalı olarak incelenerek yeterlik düzeylerinin kapsam ve niteliklerine veriler toplanmıştır. Sonraki aşamada öğretim programları kazanımlarının incelenmesine yönelik Türkiye'de iki ayrı dönemden veriler toplanmıştır. İlk incelemede araştırmacı, Milli Eğitim Bakanlı̆̆ı'nca, 2011 ve 2013 yıllarında onaylanıp, uygulanan dokuzuncu sınıf; fen bilimleri alanı (biyoloji, fizik, kimya), matematik, Türk dili ve edebiyatı derslerinin öğretim programlarından ikişer ünite kazanımları ve kapsamı incelenmiştir. İkinci inceleme ise, 2017-18 öğretim yılında yenilenen ve 2018 yılı ocak ayında tekrar güncellenerek 2018-2019 öğretim yılında uygulamaya geçecek olan aynı ögretim programları kazanımlarının içerikleri önceki kazanımlarla karşılaştırmalı incelenmiştir. İncelenen öğretim programları bilgileri aşağıdaki Tablo 2'de verilmiştir.

Tablo 2.

İncelenen 9. Sınıf Öğretim Programları Bilgileri

\begin{tabular}{|c|c|c|}
\hline Dersler & İncelenen üniteler & Onay bilgileri \\
\hline Kimya & $\begin{array}{l}\text { 9.2 Atom ve } \\
\text { Periyodik Sistem } \\
\text { 9.4 Maddenin Halleri }\end{array}$ & $\begin{array}{l}\text { TTKB (Talim Terbiye Kurulu Başkanlığı)'nın; 01.02.2013/11 ve } \\
\text { 19/01/2018-30 sayılı kararları: Ortaöğretim Kimya Dersi } \\
\text { (9-12. Sınıflar) Öğretim Programı }\end{array}$ \\
\hline Fizik & $\begin{array}{l}\text { 9.2 Madde ve Özkütle } \\
\text { 9.4 Enerji }\end{array}$ & $\begin{array}{l}\text { TTKB’nin; 01.02.2013/10 ve 19.01.2018 /28 sayılı } \\
\text { kararları: Ortaöğretim Fizik Dersi (9-12. Sinıflar) Ögretim } \\
\text { Programı }\end{array}$ \\
\hline Biyoloji & 9.3 Canlılar Dünyası & $\begin{array}{l}\text { TTKB'nin; 01.02.2013/12 ve 19.01.2018/34 sayılı } \\
\text { kararlar1: Ortaöğretim Biyoloji Dersi (9-12. Sinıflar) } \\
\text { Öğretim Programı }\end{array}$ \\
\hline Matematik & $\begin{array}{l}9.2 \text { Kümeler } \\
9.4 \text { Üçgenler }\end{array}$ & $\begin{array}{l}\text { TTKB’nin 01.02.2013/ } 9 \text { ve 19.01.2018/32 sayılı } \\
\text { kararları: Ortaöğretim Matematik Dersi (9-12. Sınıflar) } \\
\text { Öğretim Programı }\end{array}$ \\
\hline $\begin{array}{l}\text { Türk Dili ve } \\
\text { Edebiyatı }\end{array}$ & A. Okuma Teması & $\begin{array}{l}\text { TTKB’nin; } 15.08 .2011 \text { tarih ve } 114 \text { sayılı ve } 19.01 .2018 \\
\text { tarih ve } 39 \text { sayılı kararları: Ortaögretim Türk Dili } \\
\text { Edebiyatı (Dil ve Anlatım) Dersi (9-12. Sınıflar) Öğretim } \\
\text { Programları }\end{array}$ \\
\hline
\end{tabular}




\section{Verilerin analizi}

Araştırma verilerinin analizinde, "içerik ve söylem analizi" uygulanmıştır. İçerik analizi, sosyal gerçekliğin belirgin içerik özelliklerinden, belirgin olmayan özellikleri hakkında çıkarımlar yaparak sosyal gerçeği araştıran veya mevcut metinlerden hareket ederek sosyal gerçeğe yönelik önermeler elde etmeyi amaçlayan bir yöntemdir (Gökçe, 2006). Bu kapsamda Türkiye ortaöğretim dokuzuncu sınıf programları kazanımları, Anderson ve Krathwool (2014) taksonomisindeki bilgi türleri (olgusal, kavramsal, işlemsel, üstbilişsel) ve bilişsel süreçler (bilme, kavrama, uygulama, analiz, değerlendirme, yaratma) açısından incelenerek kodlanmış, frekans analizleri ve grafikleri çıkarılmıştır. İkinci aşamada üç farklı alandaki PISA yeterlik düzeylerinin içerik, yapı ve bağlam açısından kazanımlarla karşılaştırmasında Anderson ve Krathwool'un taksonomisi esas alınarak; alt, iki ve üçüncü yeterlik düzeyleri; bilgi türü açısından olgusal, kavramsal işlemsel; bilişsel nitelikler açısından ise bilme, kavrama ve uygulama niteliklerine sahip kazanımlar bu yeterlik düzeylerinde karşılaştırmada esas alınmıştır. Dört, beş ve altıncı yeterlik düzeyleri kapsamına ilișkin karşılaștırmada ise bilgi türü olarak üstbilișsel, bilişsel nitelik olarak analiz, değerlendirme ve yaratma niteliklerine sahip kazanımlar bu yeterlik düzeylerinde karşılaştırmada esas alınmıştır. Bu karşılaştırmada içerik analiz kapsamındaki, betimleme, kategorisel analiz, değerlendirme, çıkarım, ilişkisel ve yorumlayıcı analiz teknikleri uygulanmıştır (Akturan ve diğerleri, 2008; Bilgin, 2006; Gökçe, 2006; Robson, 2015).

Araştırma verilerinin söylem analizinde ise, öğretim programları kazanımları ve PISA araştırmaları yeterlik düzeylerinin içerik yapısı ve kapsamını yansıtan doküman ve belgelerin yazılı metin olarak anlamı, bu anlamın söylem olarak çözümlemesine başvurulmuştur. Bu iki veri kaynağının, içerik, yapısal ve etkileşimsel söylem özelliklerine dayalı söylem analizi sürecinde; verileri okuma ve sınıflama aşamalarına bağlı olarak yorumlama aşamasında iki veri kaynağındaki sözcükler, cümleler ve bunlar arasındaki ilişkiler yorumlanıp anlamlandırılmış, yapılandırma aşamasında sözcüklerin anlamları doğrultusunda okuması yapılmış ve makro yapılandırma sürecinde ise, söylemde yer alan sözcük veya cümlelerin pratik gerçeklikteki etki ve sonuçları irdelenmiştir (Akturan ve diğerleri, 2008; Baş, 2008; Bilgin, 2006).

Araştırma verilerinin geçerliliğinde, analiz kategorileri belirlenerek uygulanmış, yapısal geçerlik kapsamında iki farklı veri kaynağı ve iki farklı veri analiz yöntemi uygulanmış; iç geçerlikte verilerin nedenselliğine dayalı inandırıcılık, dış geçerlikte ise iki durum arasındaki ilişkiden hareketle analitik genellemelerle aktarılabilirlik esas alınmıştır. Güvenirlik kapsamında, iç güvenirlikte verilerin analizinde, analiz birimlerinin kullanılmasıyla tutarlılık; dış güvenirlikte ise farklı öğretim programları kazanımlarını inceleme ve kodlamada birer branş öğretmeni, karşılaştırmada ise uzman akademisyen görüşleri, görüş birliği odaklı tutarlılık, teyit edilebilirlik esas alınmıştır (Akar, 2016; Gökçe, 2006).

\section{Bulgular}

Türkiye'deki ortaöğretim dokuzuncu sınıf öğretim programları kazanımlarının, PISA araştırmaları yeterlik düzeylerine dağılım durumuna ilişkin araştırma bulguları; fen bilimleri (biyoloji, fizik ve kimya) dersleri, matematik dersi ve Türk dili ve edebiyatı dersi başlıkları altında incelenmiştir. İncelenen öğretim programları aşağıdaki Tablo3’te verilmiştir.

Tablo 3.

İncelenen Öğretim Programları Ünite ve Kazanımların Oranı

\begin{tabular}{llllllll}
\hline $\begin{array}{l}\text { PISA } \\
\text { Alanlar1 }\end{array}$ & $\begin{array}{l}\text { 9. Sınıf } \\
\text { Dersler }\end{array}$ & $\begin{array}{l}\text { İncelenen } \\
\text { üniteler } \\
\text { ve sırası }\end{array}$ & $\begin{array}{l}\text { Topla } \\
\text { m ünite } \\
\text { sayıs1 }\end{array}$ & $\begin{array}{l}\text { İncelenen } \\
\text { ünitelerin } \\
\text { oranı }\end{array}$ & $\begin{array}{l}\text { Íncelenen } \\
\text { kazanım } \\
\text { sayıs1 }\end{array}$ & $\begin{array}{l}\text { Dersin } \\
\text { toplam } \\
\text { kazanım } \\
\text { sayısı }\end{array}$ & $\begin{array}{l}\text { İncelenen } \\
\text { kazanım } \\
\text { oranı }\end{array}$ \\
\hline \multirow{2}{*}{$\begin{array}{l}\text { Fen } \\
\text { Bilimleri }\end{array}$} & Biyoloji & $2-3$ & 3 & .66 & 8 & 11 & .73 \\
& Fizik & $2-4$ & 6 & .33 & 12 & 44 & .27 \\
& Kimya & $2-4$ & 5 & .40 & 15 & 38 & .39 \\
\hline
\end{tabular}




\begin{tabular}{llllllll}
\hline Matematik & Matematik & $2-4$ & 5 & .40 & 21 & 41 & .51 \\
\hline \multirow{2}{*}{ Okuma } & $\begin{array}{l}\text { Türk Dili ve } \\
\text { Edebiyatı }\end{array}$ & 1 & 3 & .33 & 28 & 95 & .29 \\
\hline \multicolumn{2}{c}{ Toplam } & 9 & 24 & .38 & 84 & 229 & .37 \\
\hline
\end{tabular}

Tablo 3 incelendiğinde Türkiye örneğinde ortaöğretim dokuzuncu sınıf fen, matematik ve edebiyat derslerinin, üniteler bazında .38'i, kazanımlar bazında ise .37'si incelenmiştir. Bu genel perspektiften hareketle dersler bazında incelemelere bakılabilir.

Fen bilimleri alanı öğretim programları kazanımları ve PISA yeterlikleri

Fen bilimleri alanı kapsamında, biyoloji, fizik ve kimya dersleri öğretim programı kazanımlarının bilgi içeriği ve bilişsel nitelikler açısından analizleri yapılmıştır.

Biyoloji dersi ögretim programı kazanımları analizi: Biyoloji dersi dokuzuncu sınıf 2013 öğretim programı, 3 ünite ve 25 kazanımdan oluşurken (İşeri, 2017), 2018'de yürürlüğe giren programda ise ünite sayıs1 aynı olup, kazanımlar boyutunda dersin toplam kazanım sayıs1 25 'ten 11'e indirilmiştir. İçerik olarak "canlılar dünyası" ünitesindeki "hücre konusu" yeni programda ayrı ünite haline getirilmiştir. Güncel öğretim programının, üniteler bazında .66's1 olarak 2 ünite, kazanımlar bazında ise .73'ü olarak incelenen 8 kazanıma ilişkin veriler aşağıdaki Tablo-4'te verilmiştir.

Tablo 4.

Biyoloji Dersi Öğretim Programı İncelenen Üniteler ve Kazanımları

\begin{tabular}{|c|c|c|c|}
\hline Ünite - Konular & Kazanımlar & Bilgi türü & Bilişsel nitelik \\
\hline č: 2.1. Hücre & $\begin{array}{l}\text { 2.1.1. Hücre teorisine ilişkin çalışmaları açıklar } \\
\text { 2.1.2. Hücresel yapıları ve görevlerini açılar } \\
\text { 2.1.3. Hücre zarından madde geçişine ilişkin kontrollü } \\
\text { bir deney yapar }\end{array}$ & $\begin{array}{l}\text { Kavramsal } \\
\text { Kavramsal } \\
\text { İşlemsel }\end{array}$ & $\begin{array}{l}\text { Kavrama } \\
\text { Kavrama } \\
\text { Uygulama }\end{array}$ \\
\hline 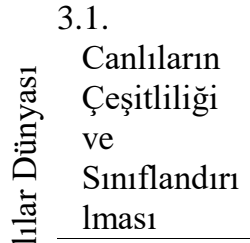 & $\begin{array}{l}\text { 3.1.1. Canlıların çeşitliliğinin anlaşılmasında } \\
\text { Sınıflandırmanın önemini açılar } \\
\text { 3.1.2. Canlıların sınıflandırılmasında kullanılan } \\
\text { kategorileri ve bu kategoriler arasındaki hiyerarşiy } \\
\text { i örneklerle açıklar }\end{array}$ & Kavramsal & Kavrama \\
\hline 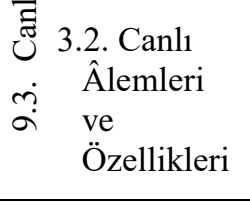 & $\begin{array}{l}\text { 3.2.1. Canlıların sınıflandırılmasında kullanılan âlemleri } \\
\text { ve bu âlemlerin genel özelliklerini açıklar. } \\
\text { 3.2.2. Canlıların biyolojik süreçlere, ekonomiye ve } \\
\text { teknolojiye katkılarını örneklerle açıklar. } \\
\text { 3.2.3. Virüslerin genel özelliklerini açıklar }\end{array}$ & Üstbilişsel & Analiz \\
\hline
\end{tabular}

Kaynak: MEB, 2013e; MEB, 2018a.

Tablo 4'te verilen, biyoloji dersi öğretim programı kazanımlarının .73'ünü oluşturan iki ünitedeki toplam 8 kazanımın içeriği, bilgi türü ve bilişsel nitelikler açısından incelenebilir. Hücre ünitesindeki üç kazanımın; bilgi içeriği olarak kavramsal ve işlemsel bilgiyi; bilişsel nitelik olarak ise kavrama ve uygulama düzeyini içeren nitelikleri; "açıklama ve deney yapma"dır. Canlılar dünyası ünitesindeki beş kazanımın; bilgi türü olarak olgusal, kavramsal ve üstbilişsel bilgiyi; bilişsel süreç olarak ise kavrama ve analiz düzeyini içeren nitelikleri; "önemini açıklar, örneklerle açıklar, özelliklerini açıklar” olduğu belirtilebilir.

Fizik dersi öğretim programı kazanımları analizi: Fizik dersi dokuzuncu sınıf 2013 öğretim programı, 5 ünite ve 43 kazanımdan oluşurken (İşeri, 2017), 2018'de yürürlüğe giren öğretim program 6 ünite ve 44 kazanımdan oluşmaktadır. Önceki programda incelenen iki ünitedeki 14 kazanım, son güncel programda 12'ye indirilmiştir. Güncel öğretim programının, üniteler bazında 
.33'ü olarak iki ünite, toplam kazanımlar bazında .27'si olarak incelenen 12 kazanıma ilişkin veriler aşağıdaki Tablo-5’te verilmiştir.

Tablo 5.

Fizik Dersi Öğretim Programı İncelenen Üniteler ve Kazanımları

\begin{tabular}{|c|c|c|c|c|}
\hline & Alt Konular & Kazanımlar & Bilgi türü & Bilişsel nitelik \\
\hline \multirow{3}{*}{ 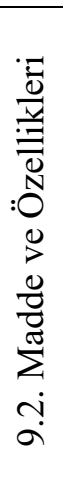 } & $\begin{array}{l}\text { 2.1. Madde ve } \\
\text { Öz kütle }\end{array}$ & $\begin{array}{l}\text { 2.1.1. Özkütleyi, kütle ve } \\
\text { hacimle ilişkilendirerek açıklar } \\
\text { 2.1.2. Günlük hayatta saf } \\
\text { maddelerin ve karışımların } \\
\text { özkütlelerinden faydalanılan } \\
\text { durumlara örnekler verir. }\end{array}$ & $\begin{array}{l}\text { Olgusal } \\
\text { Olgusal }\end{array}$ & Kavrama \\
\hline & 2.2.Dayanıklıl1k & $\begin{array}{l}\text { 2.2.1. Dayanıklılık kavramını } \\
\text { açıklar. }\end{array}$ & Olgusal & Kavrama \\
\hline & $\begin{array}{l}\text { 2.3. Yapışma ve } \\
\text { Birbirini Tutma }\end{array}$ & $\begin{array}{l}\text { 2.3.1. Yapışma (adezyon) ve } \\
\text { birbirini tutma (kohezyon) } \\
\text { olayların örneklerle açıklar }\end{array}$ & Olgusal & Kavrama \\
\hline \multirow{5}{*}{$\begin{array}{l}: \underset{\vec{\Xi}}{\leftrightarrows} \\
\text { II } \\
\dot{+} \\
\dot{0}\end{array}$} & $\begin{array}{l}\text { 4.1. İş, Enerji } \\
\text { ve Güç }\end{array}$ & $\begin{array}{l}\text { 4.1.1. İş, enerji ve güç } \\
\text { kavramlarını açıklar ve } \\
\text { birbirleriyle ilişkilendirir. } \\
\text { 4.1.2. Mekanik iş ve mekanik } \\
\text { güç ile ilgili hesaplamalar yapar }\end{array}$ & Olgusal & Kavrama \\
\hline & $\begin{array}{l}\text { 4.2. Mekanik } \\
\text { Enerji }\end{array}$ & $\begin{array}{l}\text { 4.2.1. Öteleme kinetik enerjisi, } \\
\text { yer çekimi potansiyel enerjisi ve } \\
\text { esneklik potansiyel enerjisinin } \\
\text { bağlı olduğu değişkenleri analiz } \\
\text { eder. }\end{array}$ & Üstbilişsel & Analiz \\
\hline & $\begin{array}{l}\text { 4.3. Enerjinin } \\
\text { Korunumu ve } \\
\text { Enerji } \\
\text { Dönüşümleri }\end{array}$ & $\begin{array}{l}\text { 4.3.1. Enerjinin bir biçimden } \\
\text { diğer bir biçime (mekanik, ssı, } \\
\text { 1ş1k, ses gibi) dönüşümünde } \\
\text { toplam enerjinin korunduğu } \\
\text { çıarımını yapar. } \\
\text { 4.3.2. Canlıların besinlerden } \\
\text { kazandıkları enerji ile günlük } \\
\text { aktiviteler için harcadıkları } \\
\text { enerjiyi karş1laştırır }\end{array}$ & Üstbilişsel & Analiz \\
\hline & 4.4. Verim & $\begin{array}{l}\text { 4.4.1. Verim kavramını açıklar. } \\
\text { 4.4.2. Örnek bir sistem veya } \\
\text { tasarımın verimini artıracak } \\
\text { öneriler geliştirir. }\end{array}$ & $\begin{array}{l}\text { Olgusal } \\
\text { Üstbilişsel }\end{array}$ & $\begin{array}{l}\text { Kavrama } \\
\text { Sentez }\end{array}$ \\
\hline & $\begin{array}{l}\text { 4.5. Enerji } \\
\text { Kaynakları }\end{array}$ & $\begin{array}{l}\text { 4.5.1. Yenilenebilir ve } \\
\text { yenilenemez enerji } \\
\text { kaynaklarının avantaj ve } \\
\text { dezavantajları açısından } \\
\text { değerlendirir }\end{array}$ & Üstbilişsel & Değerlendirme \\
\hline
\end{tabular}

Kaynak: MEB, 2013a; MEB, 2018b.

Tablo 5'te verilen fizik dersi öğretim programı kazanımlarının .27'sini oluşturan iki ünitedeki toplam 12 kazanımın, bilgi içeriği ve bilişsel nitelik açısından kapsamına bakılabilir. Madde ve özellikleri ünitesindeki 4 kazanımın, bilgi yapısı olarak olgusal bilgiyi; bilişsel süreç olarak kavrama düzeyini içeren nitelikleri; "açıklama ve örnekler verme"dir. Enerji ünitesindeki 8 kazanımın; bilgi içeriğgi olarak olgusal, işlemsel, üstbilişsel bilgiyi; bilişsel süreç olarak ise 
kavrama, uygulama, analiz, sentez ve değerlendirme düzeyini içeren nitelikleri; "ilişkilendirme, hesaplama yapma, analiz etme, çıkarım yapma, karşılaştırma, açılama, öneri geliştirme, değerlendirme" niteliklerinden oluşmaktadır.

Kimya dersi ögretim programı kazanımları analizi: Kimya dersi dokuzuncu sınıf 2013 öğretim programı, 4 ünite ve 72 kazanımdan oluşurken, üniteler bazında programın .50'si olarak iki ünite, kazanımlar bazında programın .25'i olarak 18 kazanım incelenmiştir (İşeri, 2017). 2018'de yürürlüğe giren öğretim programı ise 5 ünite ve 38 kazanımdan oluşmaktadır. Önceki programda incelenen 18 kazanım son güncel programda 15'e indirilmiştir. Güncel kimya dersi öğretim programının, üniteler bazında .40 'ı olarak iki ünite, toplam kazanımlar bazında .39'u olarak incelenen 15 kazanıma ilişkin veriler, aşağıdaki Tablo-6'da verilmiştir.

Tablo 6.

Kimya Dersi Öğretim Programı İncelenen Üniteler ve Kazanımları

\begin{tabular}{|c|c|c|c|c|}
\hline Ünite & / Konular & Kazanımlar & Bilgi türü & $\begin{array}{l}\text { Bilişsel } \\
\text { nitelik }\end{array}$ \\
\hline \multirow{3}{*}{ 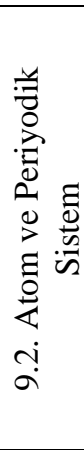 } & $\begin{array}{l}\text { 2.1. Atom } \\
\text { Modelleri }\end{array}$ & $\begin{array}{l}\text { 2.1.1. Dalton, Thomson, Rutherford ve Bohr atom } \\
\text { modellerini açıklar }\end{array}$ & Kavramsal & Kavrama \\
\hline & $\begin{array}{l}2.2 . \\
\text { Atomun } \\
\text { Yap1s1 }\end{array}$ & $\begin{array}{l}\text { 2.2.1. Elektron, proton ve nötronun yüklerini, } \\
\text { kütlelerini ve atomda bulundukları yerleri } \\
\text { karşılaştırır. }\end{array}$ & Kavramsal & Analiz \\
\hline & $\begin{array}{l}2.3 . \\
\text { Periyodik } \\
\text { Sistem }\end{array}$ & $\begin{array}{l}\text { 2.3.1. Elementlerin periyodik sistemdeki yerleşim } \\
\text { esaslarını açıklar. } \\
\text { 2.3.2. Elementleri periyodik sistemdeki yerlerine } \\
\text { göre sınıflandırır. } \\
\text { 2.3.3. Periyodik özelliklerin değişme eğilimlerini } \\
\text { açıklar. }\end{array}$ & $\begin{array}{l}\text { Kavramsal } \\
\text { Olgusal } \\
\text { Kavramsal }\end{array}$ & $\begin{array}{l}\text { Kavrama } \\
\text { Analiz } \\
\text { Kavrama }\end{array}$ \\
\hline \multirow{5}{*}{ 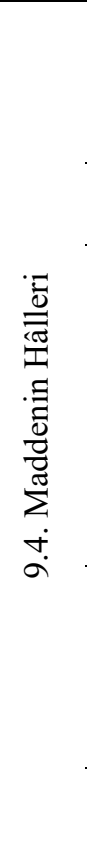 } & $\begin{array}{l}\text { M.1. } \\
\text { Maddenin } \\
\text { fiziksel } \\
\text { hâlleri }\end{array}$ & $\begin{array}{l}\text { 4.1.1. Maddenin farklı hâllerde olmasının canlılar ve } \\
\text { çevre için önemini açıklar. }\end{array}$ & Kavramsal & Kavrama \\
\hline & $\begin{array}{l}4.2 . \\
\text { Katilar }\end{array}$ & $\begin{array}{l}\text { 4.2.1. Katıların özellikleri ile bağların gücü arasında } \\
\text { ilişki kurar }\end{array}$ & Üstbilişsel & Analiz \\
\hline & $\begin{array}{l}4.3 . \\
\text { Sivilar }\end{array}$ & $\begin{array}{l}\text { 4.3.1. Sıvılarda viskozite kavramını açıklar. } \\
\text { 4.3.2. Sıvılarda viskoziteyi etkileyen faktörleri } \\
\text { açıklar. } \\
\text { 4.3.3. Kapalı kaplarda gerçekleşen buharlaşma- } \\
\text { yoğuşma süreçleri üzerinden denge buhar basıncı } \\
\text { kavramını açılar } \\
\text { 4.3.4. Doğal olayları açıklamada sıvılar ve özellikleri } \\
\text { ile ilgili kavramları kullanır. }\end{array}$ & $\begin{array}{l}\text { Olgusal } \\
\text { Kavramsal } \\
\text { Kavramsal } \\
\text { Kavramsal }\end{array}$ & $\begin{array}{l}\text { Kavrama } \\
\text { Kavrama } \\
\text { Kavrama } \\
\text { Kavrama }\end{array}$ \\
\hline & $\begin{array}{l}4.4 . \\
\text { Gazlar }\end{array}$ & $\begin{array}{l}\text { 4.4.1. Gazların genel özelliklerini açıklar. } \\
\text { 4.4.2. Gazların basınç, sıcaklık, hacim ve miktar } \\
\text { özelliklerini birimleriyle ifade eder. } \\
\text { 4.4.3. Saf maddelerin hâl değişim grafiklerini } \\
\text { yorumlar. }\end{array}$ & $\begin{array}{l}\text { Olgusal } \\
\text { Kavramsal }\end{array}$ & $\begin{array}{l}\text { Kavrama } \\
\text { Kavrama }\end{array}$ \\
\hline & $\begin{array}{l}4.5 . \\
\text { Plazma }\end{array}$ & 4.5.1. Plazma hâlini açıklar. & Olgusal & Kavrama \\
\hline
\end{tabular}

Kaynak: MEB, 2013b; MEB, 2018c.

Tablo 6'da verilen kimya dersi öğretim programı kazanımlarının .39'unu oluşturan iki ünitedeki toplam 15 kazanımın, bilgi türü ve bilişsel süreçler açısından kapsamına bakılabilir. Atom ve periyodik sistem ünitesindeki 5 kazanımın; bilgi yapısı olarak kavramsal bilgiyi; bilişsel nitelik olarak ise kavrama ve analiz düzeyini içeren nitelikleri; "açıklama, karşılaştırma, sınıflandırma" yı içermektedir. Maddenin halleri ünitesindeki 10 kazanımın; bilgi türü olarak olgusal, kavramsal, üstbilişsel bilgiyi; bilişsel süreç olarak ise kavrama ve analiz düzeyini içeren 
İşeri

nitelikleri; "açıklama, ilişkilendirme, ifade etme, kavramlarını kullanma, yorumlama" niteliklerinden oluşmaktadır.

Fen bilimleri alanı, dokuzuncu sınıf biyoloji, fizik ve kimya dersi öğretim programlarına ilişkin bu veriler bir bütün olarak okunduğunda, 14 ünitenin .42'si olarak incelenen 6 ünite; 93 kazanımın .37'si olarak incelenen 35 kazanımın yoğunlaştıkları bilişsel niteliklere ilişkin frekans değerleri ve oranlarına bakılabilir.

Tablo 7.

İncelenen Fen Bilimleri Alanı Öğretim Programları Kazanımları Kapsam Analizi

\begin{tabular}{|c|c|c|c|c|c|}
\hline Bilişsel / Bilgi & Olgusal bilgi & $\begin{array}{l}\text { Kavramsal } \\
\text { bilgi }\end{array}$ & İşlemsel bilgi & $\begin{array}{l}\text { Üstbilişsel } \\
\text { bilgi }\end{array}$ & Topl. $/ \%$ \\
\hline \multicolumn{6}{|l|}{ Bilme } \\
\hline Kavrama & $\begin{array}{l}\text { Biyoloji: } \\
3.2 .3 \\
\text { Fizik:2.1.1- } \\
2.1 .2-2.2 .1- \\
2.3 .1-4.1 .1- \\
4.4 .1 \\
\text { Kimya: } 4.3 .1- \\
4.4 .1,4.5 .1 \text {, } \\
\end{array}$ & $\begin{array}{l}\text { Biyoloji:2.1.1- } \\
2.1 .2-3.1 .1- \\
3.2 .1 \\
\text { Kimya:2.1.1- } \\
2.3 .1-2.3 .3- \\
4.1 .1-4.3 .2- \\
4.3 .3-4.3 .4- \\
4.4 .2-4.4 .3, \\
\end{array}$ & & & $23 / .66$ \\
\hline Uygulama & & & $\begin{array}{l}\text { Biyoloji: } \\
2.1 .3, \\
\text { Fizik: 4.1.2, }\end{array}$ & & $2 / .06$ \\
\hline Analiz & Kimya: 2.3 .2 & Kimya:2.2.1, & & $\begin{array}{l}\text { Biyoloji:3.1.2- } \\
\text { 3.2.2, } \\
\text { Fizik:4.2.1- } \\
4.3 .1-4.3 .2, \\
\text { Kimya: } 4.2 .1 \\
\end{array}$ & $8 / .22$ \\
\hline Değerlendirme & & & & Fizik: 4.5.1 & $1 / .03$ \\
\hline Yaratma & & & & Fizik:4.4.2, & $1 / .03$ \\
\hline Top./Oran & $11 / .31$ & $15 / .42$ & $2 / .05$ & $8 / .22$ & $35 / .100$ \\
\hline
\end{tabular}

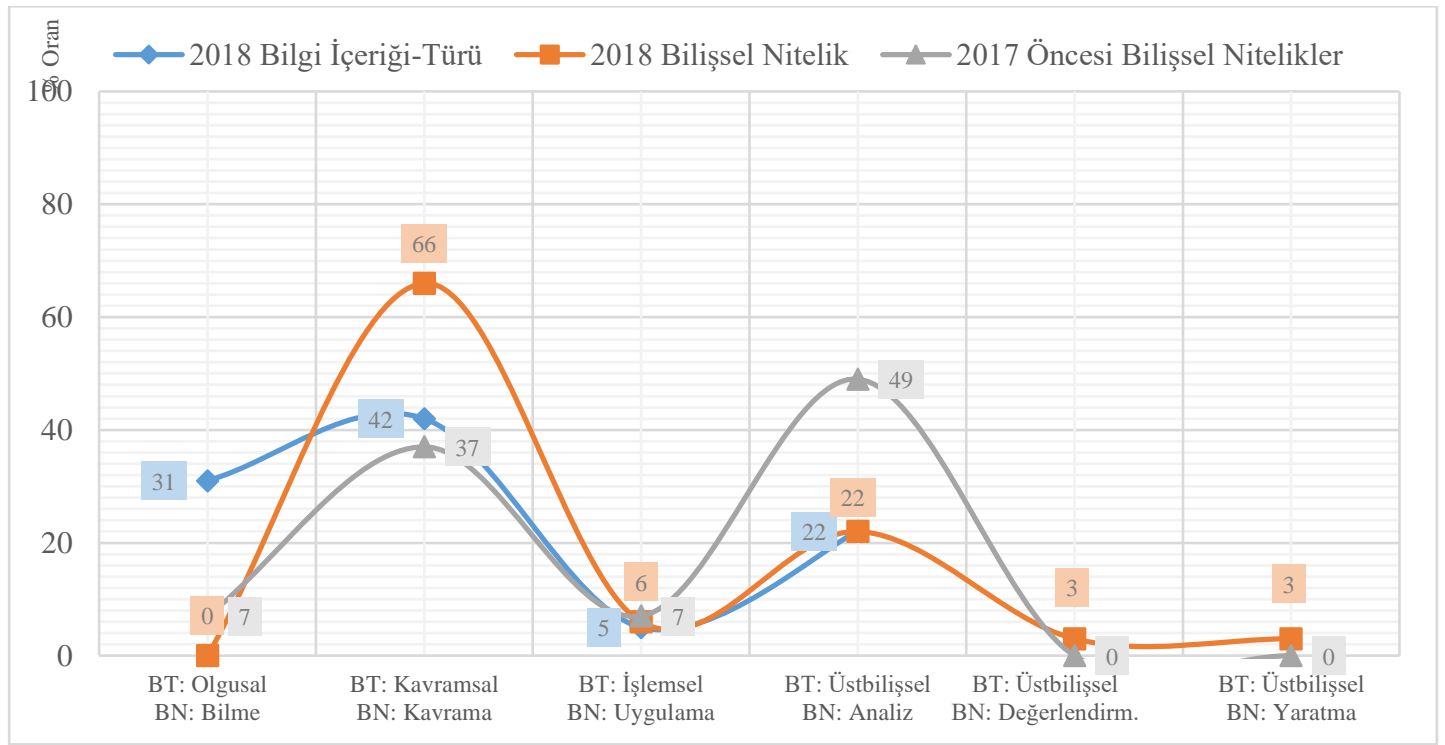

(BT: Bilgi Türü; BN: Bilișsel Nitelik)

Şekil 1. Fen Bilimleri Dersleri Öğretim Programları Kazanımlarının Nitelik Dağılımı 
Fen bilimleri alanına ilişkin yukarıdaki Tablo-7 ve Şekil-1 birlikte incelendiğinde; biyoloji, fizik, kimya dersleri öğretim programları kazanımlarının bilgi türü-niteliği açısından, .31'i olgusal, .42'si kavramsal, .05'i işlemsel, .22'si üstbilişsel bilgi türlerinde yoğunlaşırken; bilişsel nitelikler boyutunda ise .66's1 kavrama, .06's1 uygulama, .22'si analiz, .03'ü değerlendirme ve yine .03 'ü yaratma düzeylerinde yoğunlaştı̆g 1 belirtilebilir. 2013 fen bilimleri programlarında ise kazanımların bilişsel nitelik olarak, .07'si bilme, .37'si kavrama, .07'si uygulama ve .49'u analiz düzeyinde yoğunlaşmıştır (İşeri, 2017). Bu durum, kazanımların üst düzey bilişsel nitelik oranının azaldığı kavrama düzeyi oranının yükseldiğini göstermektedir.

Fen bilimleri alanı kazanımlarının pısa fen alanı yeterlik düzeylerine dağılımı: PISA fen okuryazarlığı, 6 yeterlik düzeyinin kapsamı üç boyuttan oluşmaktadır. Olguları bilimsel olarak açıklama, bilimsel sorgulama yöntemi tasarlama ve değerlendirme, verileri ve bulguları bilimsel olarak yorumlama boyutlarını içermektedir.

Tablo 8.

PISA Fen Alanı Yeterlilik Düzeyleri ve Türkiye Fen Bilimleri Kazanımları İlişkisi

\begin{tabular}{|c|c|c|c|c|c|}
\hline \multirow{2}{*}{\multicolumn{2}{|c|}{ PISA fen okuryazarlığı yeterlik düzeyleri }} & \multicolumn{4}{|c|}{ Fen bilimleri alanı kazanım kodları } \\
\hline & & Biyoloji & Fizik & Kimya & Top. $1 \%$ \\
\hline \multicolumn{6}{|c|}{$\begin{array}{l}\text { Bu düzeydeki öğrenciler, alışılmamış bilimsel olgulara, } \\
\text { olaylara ve süreçlere açiklayıcı hipotezler sunmak veya } \\
\text { tahminler yapmak için içerik, süreç ve epistemik bilgiyi, } \\
\text { kullanabilir ve fizik, canlı ile uzay ve yer bilimlerindeki bir } \\
\text { dizi fikir ve kavramı anlayabilir. Bilgi-bulguları } \\
\text { Ðै yorumlamada ilgili-ilgisiz bilgileri ayırt edebilir ve normal } \\
\text { okul programının dışındaki bilgiyi elde edebilir. Bilimsel } \\
\text { kanıt, yasalara dayanan bilgilerle diğer görüşlere dayanan } \\
\text { bilgileri ayırt edebilir. Birbirinin yerine kullanılabilecek } \\
\text { karmaşı deney düzenekleri, alan çalışmaları ve } \\
\text { simülasyonları değerlendirebilir ve seçimlerini } \\
\text { gerekçelendirebilir. }\end{array}$} \\
\hline 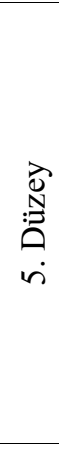 & $\begin{array}{l}\text { Bu düzeydeki öğrenciler, soyut bilimsel fikir ve kavramları; } \\
\text { çok yönlü nedensellik bağlantıları içeren karmaşı olgu, } \\
\text { olay ve süreçleri açılamak için kullanabilir. Alternatif } \\
\text { deneysel tasarımları deģerlendirmek, kararlarını } \\
\text { doğrulamak için daha karmaşk epistemik bilgiye } \\
\text { başvurabilir ve tahminler yapmak veya bilgileri } \\
\text { yorumlamak için teorik bilgiyi kullanabilir. Belirli bir } \\
\text { soruyu bilimsel olarak araştırmanı yollarını } \\
\text { değerlendirebilir ve kaynakların dahil olduğu veri setlerinin } \\
\text { yorumlarındaki sinırlılıkları ve bilimsel verideki } \\
\text { belirsizliğin etkilerini saptar. }\end{array}$ & & 4.4.2, & & $1 / .03$ \\
\hline 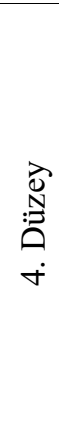 & $\begin{array}{l}\text { Bu düzeydeki öğrenciler, daha karmaşık veya daha az } \\
\text { tanıdı olan olaylara ve süreçlere ilişkin açıklamalarını } \\
\text { oluşturmak için verilen ya da hatırlanan daha karmaşı veya } \\
\text { daha soyut içerik bilgisini kullanabilir. Sınırlandırılmış bir } \\
\text { bağlamda iki veya daha fazla bağımsız değişkeni içeren } \\
\text { deneyleri uygulayabilir. Epistemik ve süreç bilgisinin } \\
\text { unsurların kullanarak deneysel bir tasarımı doğrulayabilir. } \\
\text { Orta derecede karmaşı veri setindeki ya da daha az bilindik } \\
\text { bir bağlamdan elde edilen veriyi yorumlayabilir. Verinin } \\
\text { ötesinde uygun sonuçlar çıkarabilir ve seçimlerine gerekçe } \\
\text { sunabilir. }\end{array}$ & 3.1.2, & 4.5.1 & & $2 / .06$ \\
\hline
\end{tabular}




\begin{tabular}{|c|c|c|c|c|c|}
\hline 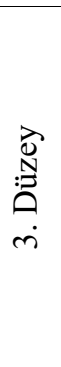 & $\begin{array}{l}\text { Bu düzeydeki öğrenciler, orta derecede karışı olan içerik } \\
\text { bilgisini bilindik olguların açıklamalarını oluşturmak ve } \\
\text { tanımlanmak için kullanabilir. Daha az bilindik veya daha } \\
\text { karmaşık durumlarda konuyla alakalı ipucu veya destekle } \\
\text { açıklamalar oluşturabilir. Sınırlı bir bağlamda basit bir } \\
\text { deneyi uygulamada epistemik bilgi ve süreç bilgisinin } \\
\text { unsurlarından yararlanır. Bilimsel ve bilimsel olmayan } \\
\text { sorunları ayırt edebilir ve bilimsel ifadeyi destekleyen } \\
\text { bulguyu fark edebilir. }\end{array}$ & 2.1.3, & 4.2.1, & 4.3.3, & $3 / .09$ \\
\hline 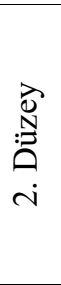 & $\begin{array}{l}\text { Bu düzeydeki öğrenciler, günlük içerik bilgisini ve temel } \\
\text { süreç bilgisini, bilimsel açıklamayı tanımlamak, veriyi } \\
\text { yorumlamak ve basit deneysel soruyu belirlemek için } \\
\text { kullanabilir. Temel veya her günkü bilimsel bilgiyi, basit bir } \\
\text { veri setinde geçerli sonucu açılamak kullanabilir. Bilimsel } \\
\text { olarak araştırılabilecek sorulara temel oluşturan temel } \\
\text { epistemik bilgiyi gösterebilir }\end{array}$ & 3.2.2, & $\begin{array}{l}4.3 .2, \\
4.1 .2\end{array}$ & 4.3.4, & $4 / .11$ \\
\hline 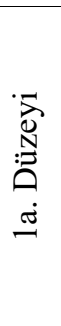 & $\begin{array}{l}\text { Bu düzeydeki öğrenciler, temel veya günlük içerik bilgisini } \\
\text { basit bilimsel olgunun açıklamalarını ayırt etmek ve } \\
\text { saptamak için kullanabilir. Yardım alarak ikiden fazla } \\
\text { değişkeni olmayan yapılandırılmış bilimsel sorgulamaları } \\
\text { yapar. Basit nedensel ve ilişkisel bağlantıları saptayabilir ve } \\
\text { düşük seviyede bilişsel istem gerektiren grafiksel ve görsel } \\
\text { veriyi yorumlayabilir ve bilindik yerel ve kişisel } \\
\text { bağlamlarda verilen veri için en iyi açıklamayı seçebilir. }\end{array}$ & $\begin{array}{l}\text { 2.1.1, } \\
3.1 .1,\end{array}$ & $\begin{array}{l}\text { 2.1.2, } \\
4.3 .1\end{array}$ & $\begin{array}{l}\text { 4.1.1, } \\
2.2 .1 \\
2.3 .3 \\
4.2 .1 \\
4.3 .2 \\
2.3 .1 \\
2.3 .2 \\
4.4 .3\end{array}$ & $12 / .34$ \\
\hline \multirow[t]{2}{*}{ 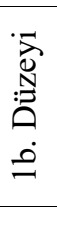 } & $\begin{array}{l}\text { Bu düzeydeki öğrenciler, bilindik veya basit olgunun } \\
\text { özelliklerini ayırt etmek için günlük bilgiyi kullanabilir. } \\
\text { Verideki basit örüntüleri tanımlayabilir, basit bilimsel } \\
\text { terimleri ayırt edebilir ve bilimsel bir süreci uygulamak için } \\
\text { açık olan yönergeleri takip edebilir. }\end{array}$ & $\begin{array}{l}3.2 .1, \\
2.1 .2, \\
3.2 .3,\end{array}$ & $\begin{array}{l}2.3 .1 \\
2.1 .1 \\
4.1 .1 \\
2.2 .1 \\
4.4 .1\end{array}$ & $\begin{array}{l}2.1 .1 \\
4.4 .1 \\
4.4 .2 \\
4.3 .1 \\
4.5 .1\end{array}$ & $13 / .37$ \\
\hline & Toplam & 8 & 12 & 15 & $35 / .100$ \\
\hline
\end{tabular}

Kaynak: OECD, 2014; OECD, 2016b; MEB, 2010a-b; MEB, 2015; MEB, 2016.

Tablo 8 incelendiğinde, Türkiye fen bilimleri alanı öğretim programları kazanımlarının, PISA yeterlik düzeylerine dağılımında kazanımların: .71'inin alt yeterlik düzeylerine, .11'inin temel asgari yeterlik düzeyi olan ikinci düzeye, .18'inin ise üçüncü düzey ve üstündeki düzeylere yoğunlaştı̆̆ görülmektedir. Bu durum 2013 fen alanı öğretim programları kazanımlarının, yeterlik düzeylerine dağılımıyla karşılaştırıldığında; kazanımların; .60'1 alt yeterlik düzeylerine, .35'inin ikinci düzeye, 05 'inin ise üçüncü düzey ve üstündeki düzeylere yoğunlaşttğg belirtilebilir (İşeri, 2017). Bu verilerden hareketle güncel programda, üst yeterlik düzeylerindeki kazanım oranının .05 'ten, .18'e yükseldiği, temel asgari yeterlikleri içeren ikinci düzeydeki kazanım oranının .35 'ten .11 'e düştügüu, alt yeterlik düzeylerindeki kazanım oranının .60 'tan .71 'e yükseldiği belirtilebilir. Bu bağlamda Türkiye fen bilimleri alanı öğretim programı kazanımlarının PISA yeterlik düzeylerine dağılımı oranı ile Türkiye'nin PISA fen bilimleri alanı öğrenci performans oranlarının yeterlik düzeylerine dağılımı karşılaştırılabilir. 


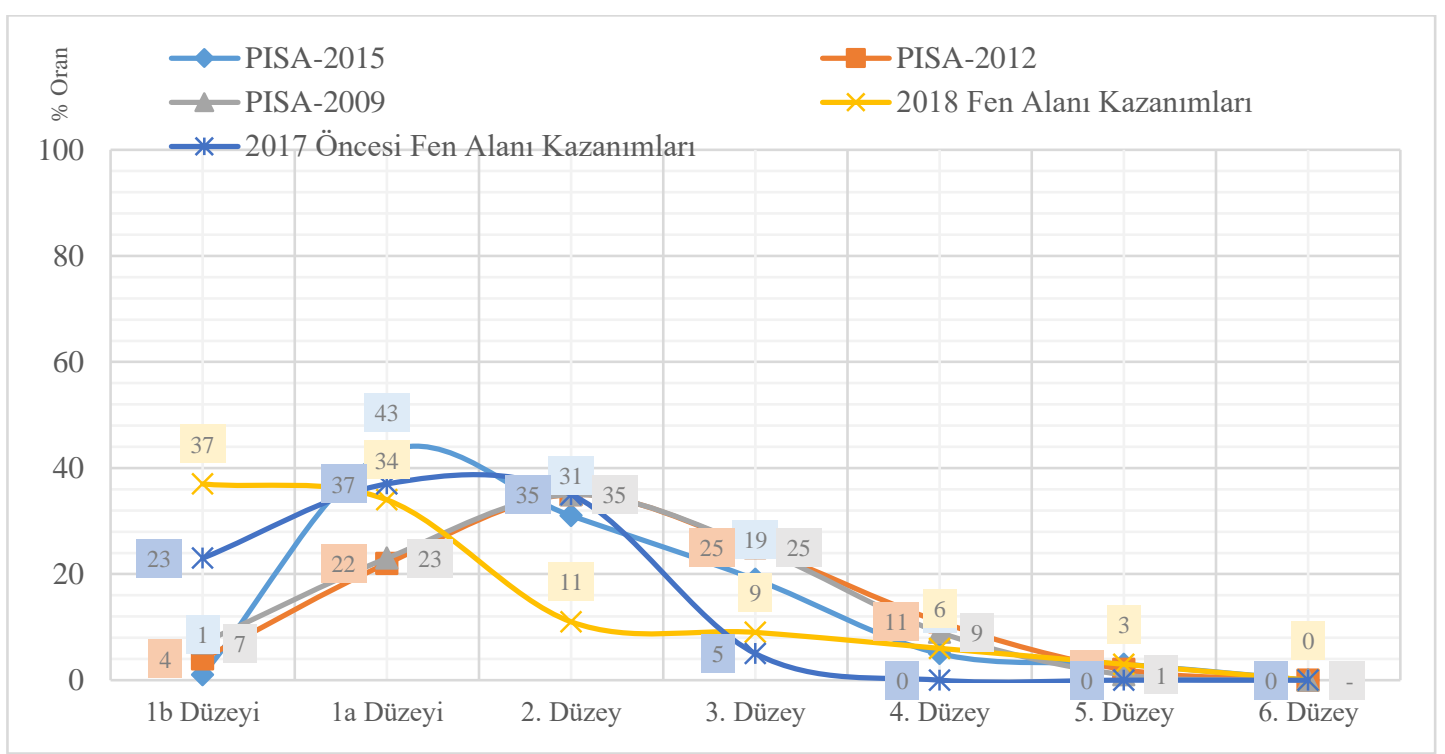

Şekil 2. Türkiye, PISA Fen Alanı Performansı ve Fen Bilimleri Dersleri Kazanımları İlişkisi

Şekil 2 incelendiğinde, Türkiye fen bilimleri alanı dokuzuncu sınıf öğretim programı kazanımlarının PISA yeterlik düzeylerine dağılımı oranı ile Türkiye'nin PISA fen okuryazarlığı performansının yeterlik düzeylerine dağılım oranı karşılaştırıldı̆̆ında; hem öğretim programı kazanımlarının hem de öğrenci performansının, ikinci yeterlik düzeyi ve alt yeterlik düzeylerine yoğunlaştığı belirtilebilir. Buna bağlı olarak üst yeterlik düzeylerinde ise hem kazanımların hem öğrenci performansının olmaması da bu örtüşmenin diğer bir boyutu olarak görülebilir. Bu durum fen okuryazarlığı alanında Türkiye'nin alt yeterlik düzeylerindeki öğrenci oranının, OECD ülkeleri ile tüm ülkeler ortalamasından yüksek olması; beşinci düzey ve üstünde bulunan öğrenci oranının da tüm ülkeler ve OECD ülkeleri ortalamasından düşük olması (OECD, 2013a; MEB, 2016) durumu, PISA-2015 fen okuryazarlığına yönelik duyuşsal özelliklerle okunduğunda, Türkiye'deki öğrencilerin fen derslerine ilişkin olumlu tutum, ilgi ve motivasyona sahip olma oranının, OECD ortalamasından daha yüksek olmasına rağmen düşük başarı performansı (MEB, 2016), Türkiye'deki fen bilimleri alanı kazanımlarının yukarıdaki belirlenen düşük nitelikleriyle açıklanabilir.

\section{Matematik alanı öğretim programı kazanımları ve PISA yeterlikleri}

Matematik dersi dokuzuncu sınıf 2013 öğretim programı, 7 ünite ve 47 kazanımdan oluşurken, üniteler bazında programın .28'i, kazanımlar bazında .59'u incelenmiştir (İşeri, 2017). 2018'de yürürlüğe giren öğretim programı, 5 ünite ve 41 kazanımdan oluşurken, 2017 öncesi programın iki ünitesindeki 28 kazanım, son güncellenen programda 21'e düşürülmüştür. Bu bağlamda güncel programın üniteler bazında .40 '1 olarak 2 ünite, toplam kazanımlar bazında .51 'i olarak incelenen 21 kazanıma ilişkin veriler aşağıdaki Tablo-9'da verilmiştir.

Tablo 9.

Matematik Dersi Öğretim Programı İncelenen Üniteler ve Kazanımları

\begin{tabular}{|c|c|c|c|c|}
\hline Ünite & Konular & Kazanımlar & Bilgi türü & Bilişsel nitelik \\
\hline$\frac{\dot{\theta}}{0}$ & $\begin{array}{l}\text { 2.1. Kümelerde } \\
\text { Temel } \\
\text { Kavramlar }\end{array}$ & $\begin{array}{l}\text { 2.1.1. Kümeler ile ilgili temel kavramlar } \\
\text { hatırlatılır. } \\
\text { 2.1.2. Alt kümeyi kullanarak işlemler yapar. } \\
\text { 2.1.3. İki kümenin eşitliğini kullanarak işlemler } \\
\text { yapar }\end{array}$ & $\begin{array}{l}\text { Olgusal } \\
\text { İşlemsel } \\
\text { İşlemsel }\end{array}$ & $\begin{array}{l}\text { Bilme } \\
\text { Uygulama } \\
\text { Uygulama }\end{array}$ \\
\hline 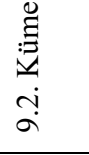 & $\begin{array}{l}\text { 2.2. Kümelerde } \\
\text { İşlemler }\end{array}$ & $\begin{array}{l}\text { 2.2.1. Kümelerde birleşim, kesişim, fark, } \\
\text { tümleme işlemleri yardımıyla problemler çözer. } \\
\text { 2.2.2. İki kümenin kartezyen çarpımıyla ilgili } \\
\text { işlemler yapar }\end{array}$ & $\begin{array}{l}\text { İşlemsel } \\
\text { İşlemsel }\end{array}$ & Uygulama \\
\hline
\end{tabular}




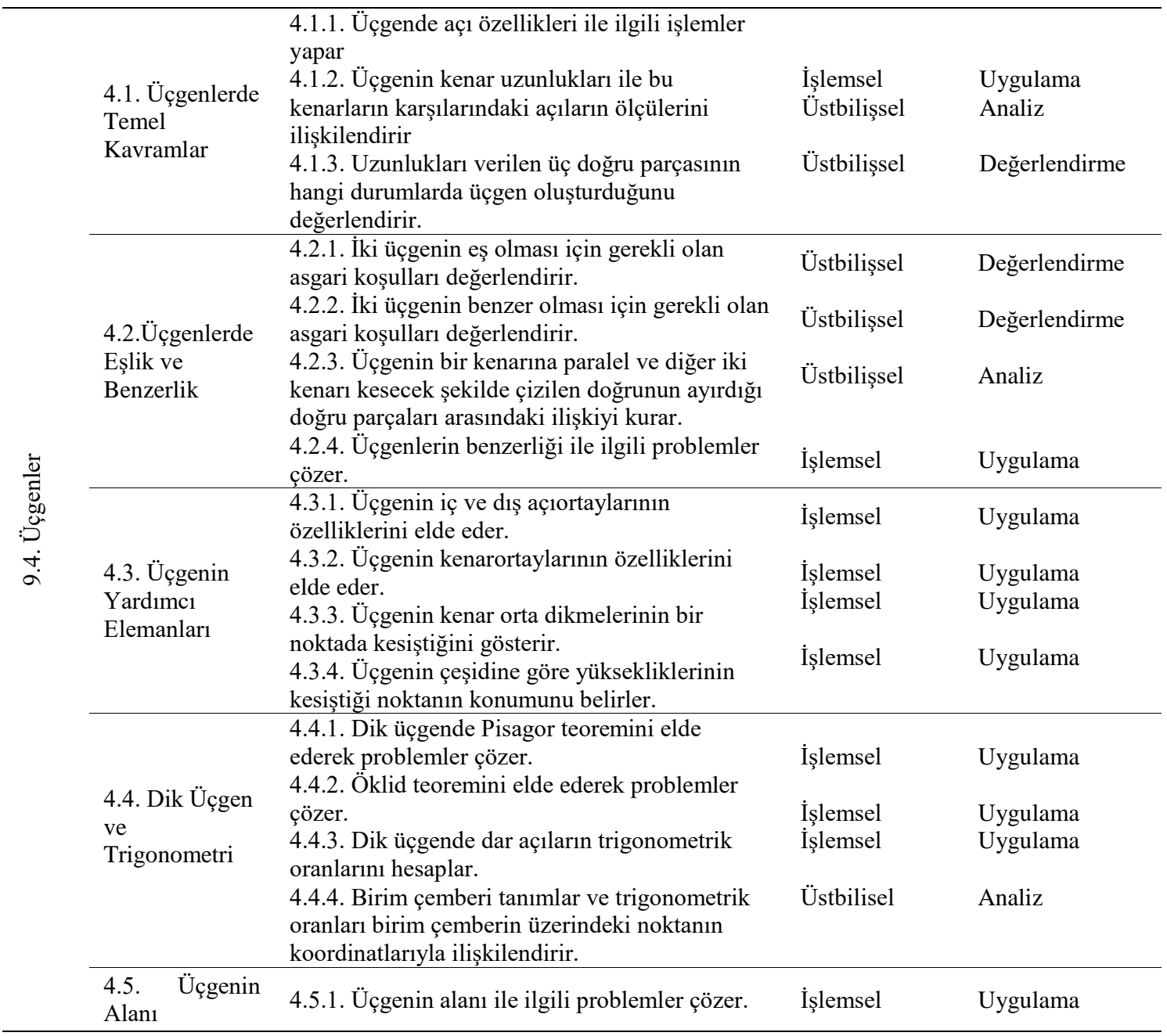

Kaynak: MEB, 2013c, 2018d

Tablo 9'da matematik dersi öğretim programı kazanımlarının .51'ini oluşturan iki ünitedeki toplam 21 kazanımın kapsamına bilgi türü ve bilişsel nitelikler boyutunda bakılabilir. Kümeler ünitesindeki 5 kazanımın; bilgi türü olarak olgusal ve işlemsel bilgiyi ve bilişsel nitelik olarak bilme ve uygulama düzeyini içeren nitelikleri; "hatırlama, işlem yapma ve problem çözme"yi içermektedir. Üçgenler ünitesindeki 16 kazanımın; bilgi içeriği olarak işlemsel ve üstbilişsel bilgiyi; bilişsel nitelik olarak ise uygulama, analiz ve değerlendirme düzeylerini içeren nitelikleri; "işlem yapma, ilişkilendirme, değerlendirme, problem çözme, konumu belirleme, hesaplama"yı içermektedir.

Tablo 10.

İncelenen Matematik Dersi Öğretim Programı Kazanımlarının Kapsam Analizi

\begin{tabular}{|c|c|c|c|c|c|}
\hline Bilişsel / Bilgi & $\begin{array}{l}\text { Olgusal } \\
\text { bilgi }\end{array}$ & $\begin{array}{l}\text { Kavramsal } \\
\text { bilgi }\end{array}$ & İşlemsel bilgi & $\begin{array}{l}\text { Üstbilişsel } \\
\text { bilgi }\end{array}$ & Topl. $1 \%$ \\
\hline Bilme & 2.1.1, & & & & $1 / .05$ \\
\hline \multicolumn{6}{|l|}{ Kavrama } \\
\hline Uygulama & & & $\begin{array}{l}2.1 .2-2.1 .3-2.2 .1, \\
2.2 .2-4.1 .1- \\
4.2 .4-4.3 .1-4.3 .2, \\
4.3 .3-4.3 .4-4.4 .1, \\
4.4 .2-4.4 .3-4.5 .1\end{array}$ & & 14 / .66 \\
\hline
\end{tabular}




\begin{tabular}{|c|c|c|c|}
\hline Analiz & & $\begin{array}{l}\text { 4.1.2-4.2.3- } \\
4.4 .4,\end{array}$ & $3 / .14$ \\
\hline Değerlendirme & & $\begin{array}{l}\text { 4.1.3-4.2.1- } \\
4.2 .2,\end{array}$ & $3 / .14$ \\
\hline \multicolumn{4}{|l|}{ Yaratma } \\
\hline Top./Oran & $14 / .66$ & $6 / .29$ & $21 / .100$ \\
\hline
\end{tabular}

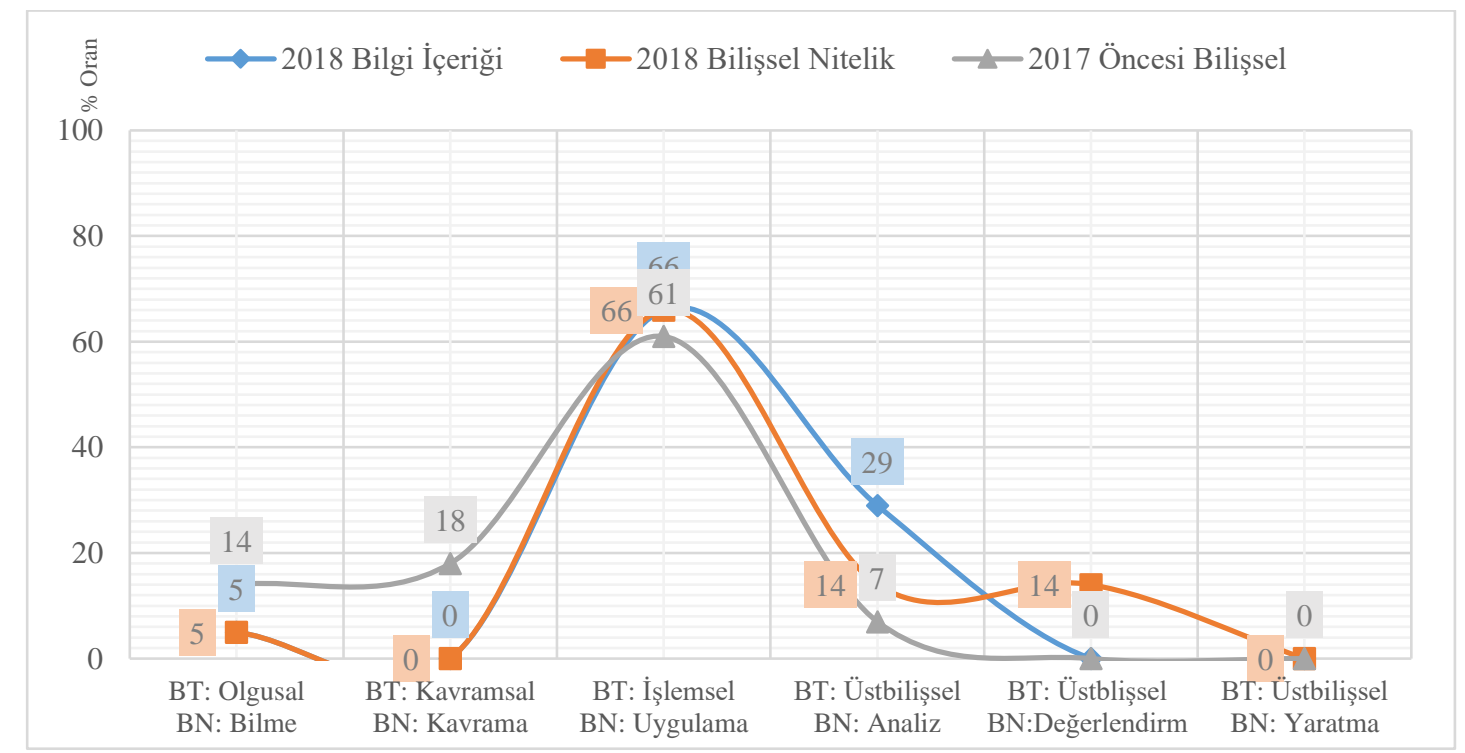

(BT: Bilgi Türü; BN: Bilişsel Nitelik)

Şekil 3. Matematik Dersi Öğretim Programı Kazanımlarının Nitelik Dağılımı

Matematik alanına ilişkin yukarıdaki Tablo 10 ve Şekil 3 birlikte incelendiğinde, matematik dersi öğretim programı kazanımların; bilgi türü açısından .05'i olgusal, .66'sı işlemsel ve .29'u ise üstbilişsel bilgi türlerinde yoğunlaşırken; bilişsel nitelikler boyutunda ise .05 'i bilme, .66'sı uygulama, .14'ü analiz ve yine .14'ünün de değerlendirme düzeylerinde yoğunlaştığ 1 belirtilebilir. 2013 programında ise kazanımların bilişsel nitelik olarak .14'ü bilme, .18'i kavrama, .61'i uygulama ve .07'si ise analiz düzeyinde yoğunlaşmıştır (İşeri, 2017). Bu veriler, kazanımların üst düzey bilişsel nitelikler açısından azaldığını göstermektedir.

Matematik ögretim programları kazanımlarının PISA matematik alanı yeterlik düzeylerine dağılımı: PISA matematik okuryazarlığı altı yeterlik düzeyi iki boyuttan oluşmaktadır. İlk boyut olan matematiksel düşünme eylemleri boyutu; matematiksel kavram, bilgi ve beceriler, matematiksel yeterlikler ve matematiksel süreçlerden oluşmaktadır. İkinci boyut olan gerçek yaşam durumları boyutu ise, matematiksel içerik kategorisi ve gerçek yaşam kategorisini içermektedir (MEB, 2013d, 2016; OECD, 2016a,b). Bu bağlamda, Türkiye dokuzuncu sınıf matematik öğretim programından incelenen iki ünitedeki toplam 21 kazanımın, PISA matematik alanı yeterlik düzeylerine dağılımıyla Türkiye'nin PİSA matematik okuryazarlığı performansının yeterlik düzeylerine dağılımı karşıllaştırılabilir. 
Tablo 11

Matematik Alanı Kazanımlarının PISA Matematik Alanı Yeterlik Düzeylerine Dağılımı

\begin{tabular}{|c|c|c|c|}
\hline \multicolumn{2}{|r|}{ PISA matematik alanı yeterlik düzeyleri } & Kazanımlar & Top. $1 \%$ \\
\hline 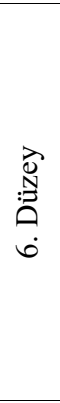 & $\begin{array}{l}\text { Bu düzeyde yer alan öğrenciler; araştırmalarına bağlı olarak elde ettikleri } \\
\text { bilgileri kavramlaştırabilir, genelleyebilir ve kullanabilir. Karmaşık } \\
\text { problem durumları modelleyebilir. Farklı bilgi kaynaklarını ve } \\
\text { gösterimlerini ilişkilendirebilir. Bunları esnek bir şekilde birbirine } \\
\text { dönüştürebilir. İleri düzeyde matematiksel düşünme ve akıl yürütme } \\
\text { kapasitesine sahiptir. Yeni durumlarla başa çıkmaya yönelik yeni } \\
\text { yaklaşımlar ve stratejiler geliştirmede, sembolik ve formal matematik } \\
\text { işlemleri ve ilişkilerinin yanı sıra, kendi bakış açılarını ve anlamlarını } \\
\text { uygulayabilir. Kendi bulgularına, yorumlarına, argümanlarına ve bunların } \\
\text { orijinal durumlara uygunluğuna bağlı olarak eylemlerini ve tepkilerini } \\
\text { formüle edebilir ve bunlar arasındaki iletişimi tam olarak sağlayabilir. }\end{array}$ & & \\
\hline 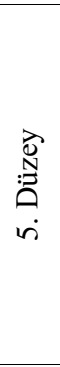 & $\begin{array}{l}\text { Bu düzeyde yer alan öğrenciler; karmaşık durumlara yönelik modeller } \\
\text { geliştirebilir ve bu modellerle çalışabilir. Sınırlılıkları ve belirli } \\
\text { varsayımları tanımlayabilir. Bu modellerle ilişkili karmaşı problemlerle } \\
\text { başa çıkmaya yönelik uygun problem çözme stratejilerini seçebilir, } \\
\text { karşılaşırabilir ve değerlendirebilir. Geniş ve iyi yapılandırılmış düşünme } \\
\text { ve akıl yürütme becerilerini, ilişkilendirilmiş uygun gösterimleri, sembolik } \\
\text { ve formel tanımlamaları ve bu durumlara yönelik bakış açılarını kullanarak } \\
\text { stratejik bir şekilde çalışabilir. Kendi eylemlerini ve formülleştirmelerini } \\
\text { yansıtabilir. Kendi yorumları ve akıl yürütmelerine bağlı olarak elde ettiği } \\
\text { çıarımları arasında iletişim kurabilir. }\end{array}$ & & \\
\hline 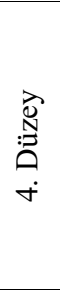 & $\begin{array}{l}\text { Bu düzeyde yer alan öğrenciler; varsayımların sağlanması ya da sınırlılıklar } \\
\text { içerebilen karmaşı durumlara yönelik açık modellerle etkili bir şekilde } \\
\text { çalışabilir. Sembolik gösterimler içeren farklı gösterimleri seçebilir ve } \\
\text { entegre edebilir. Bunlarla gerçek problem durumları arasındaki bağlantıları } \\
\text { doğrudan kurabilir. Iyyi yapılandırılmış becerileri ve esnek akıl yürütmeleri, } \\
\text { bu içerikteki bazı bakış açılarıyla kullanabilir. Kendi yorumlarına, } \\
\text { argümanlarına ve eylemlerine dayalı açıklamaları ve tartışmaları inşa } \\
\text { edebilir ve ilişkilendirebilir }\end{array}$ & & \\
\hline 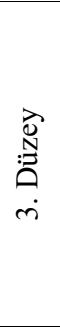 & $\begin{array}{l}\text { Bu düzeyde yer alan öğrenciler; bir dizi aşamalı kararların verilmesini } \\
\text { içeren açıkça tanımlanmış işlemleri yürütebilir. Basit problem çözme } \\
\text { stratejilerini seçebilir ve uygulayabilir. Farklı bilgi kaynakları ve bunlardan } \\
\text { doğrudan çıkarımlar yapılmasına dayalı gösterimleri yorumlayabilir ve } \\
\text { kullanabilir. Yorumlarını, sonuçlarını ve akıl yürütmeleri ile elde ettiği } \\
\text { çıkarımlarını raporlaştırırken bunlar arasındaki ilişkileri sınırlı ve kısa } \\
\text { şekilde kurabilir. }\end{array}$ & $\begin{array}{l}\text { 4.4.1, } \\
4.4 .2, \\
4.4 .3 \\
4.4 .4, \\
2.2 .1 \\
4.2 .4 \\
4.5 .1 \\
4.1 .2 \\
4.2 .3\end{array}$ & $9 / .43$ \\
\hline 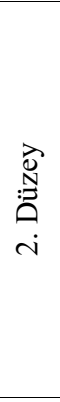 & $\begin{array}{l}\text { Bu düzeyde yer alan öğrenciler; doğrudan yani ilk bakışta görülenden } \\
\text { fazlasını gerektirmeyen belli bir içerikteki durumları fark edebilir ve } \\
\text { yorumlayabilir. Tek bir kaynakla ilişkili bilgileri ortaya çıkarabilir ve bu } \\
\text { bilgileri tek bir gösterimde kullanabilir. Temel algoritma, formül, işlem ve } \\
\text { alışıldık kuralları işe koşabilir. Doğrudan yani ilk bakışta görülen basit } \\
\text { ilişkilere yönelik akıl yürütme kapasitesine sahiptir ve sonuçları sınırlı bir } \\
\text { şekilde yorumlayabilir }\end{array}$ & $\begin{array}{l}\text { 4.2.1, } \\
4.2 .2, \\
2.1 .2, \\
2.1 .3 \\
2.2 .2 \\
4.3 .1 \\
4.3 .2 \\
4.1 .1 \\
4.1 .3 \\
4.3 .3 \\
4.3 .4\end{array}$ & $\begin{array}{c}11 \\
/ .52\end{array}$ \\
\hline $\begin{array}{l}\text { 灰 } \\
: \\
:\end{array}$ & $\begin{array}{l}\text { Bu düzeyde yer alan öğrenciler; tüm ilişkili bilgilerin verildiği ve soruların } \\
\text { açıkça tanımlandığı bilindik içerikteki soruları yanıtlayabilir. Açık } \\
\text { durumlara yönelik doğrudan verilen yönergelere göre bilgiyi tanıyabilir ve } \\
\text { rutin işlemleri ortaya çıarabilir. Açık ve özendirici verilen eylemlerde } \\
\text { performans gösterebilir }\end{array}$ & 2.1.1, & $1 / .05$ \\
\hline & Toplam & & $\begin{array}{c}21 / \\
.100 \\
\end{array}$ \\
\hline
\end{tabular}

Kaynak: OECD, 2014; OECD, 2016b; MEB, 2010a-b; MEB, 2015; MEB, 2016. 
Tablo 11 incelendiğinde, Türkiye matematik alanı 9. Sınıf öğretim programı kazanımlarının, PISA yeterlik düzeylerine dağılımında kazanımların; .05'inin alt yeterlik alanı olan birinci düzey, .52'sinin temel asgari yeterlikleri içeren ikinci düzey, .43'ünün üçüncü düzey ve üstündeki yeterlik düzeylerinde yoğunlaştığı belirtilebilir. Bu durum 2013 matematik öğretim programı kazanımlarının, yeterlik düzeylerine dağılımıyla karşılaştırıldığında İşeri (2017) kazanımların; .21'inin alt yeterlik düzeylerine, .29'unun temel asgari yeterlikleri içeren ikinci düzey, .49'unun üçüncü düzey ve üstündeki yeterlik düzeylerine yoğunlaştı̆̆ belirtilebilir. Bu veriler iki farklı dönemdeki kazanımların, alt yeterlik alanlarındaki oranının, .21'den .05'e düştügü, temel asgari yeterlikleri içeren ikinci düzeydeki kazanımların .29'dan .52'ye yükseldiği, üçüncü düzey ve üstündeki kazanımların ise .49'dan .43'e düştüğü belirtilebilir. Bu bağlamda, Türkiye matematik alanı kazanımlarının bu yeterlik düzeylerine dağılımı oranı ile Türkiye'nin PISA matematik performansının yeterlik düzeylerine dağılım oranları karşılaştırılabilir.

Şekil 4 incelendiğinde, Türkiye matematik alanı 9 . Sınıf öğretim programı kazanımlarının PISA yeterlik düzeylerine dağılımı oranı ile Türkiye'nin PISA matematik performansının yeterlik düzeylerine dağılım oranları karşılaştırılabilir. Öğrenci performansının ikinci düzey ve alt yeterlik düzeylerine; iki farklı dönemde geliştirilen öğretim programı kazanımlarının ise iki ve üçüncü yeterlik düzeylerine yoğunlaştığı; üst yeterlik düzeylerinde ise hem kazanımların hem de öğrenci performansı çok sınırlı olduğu belirtilebilir. Bu durum, matematik alanı kazanımların bilgi türü ve bilişsel niteliklerinin düşüklüğüyle açıklanabilir.

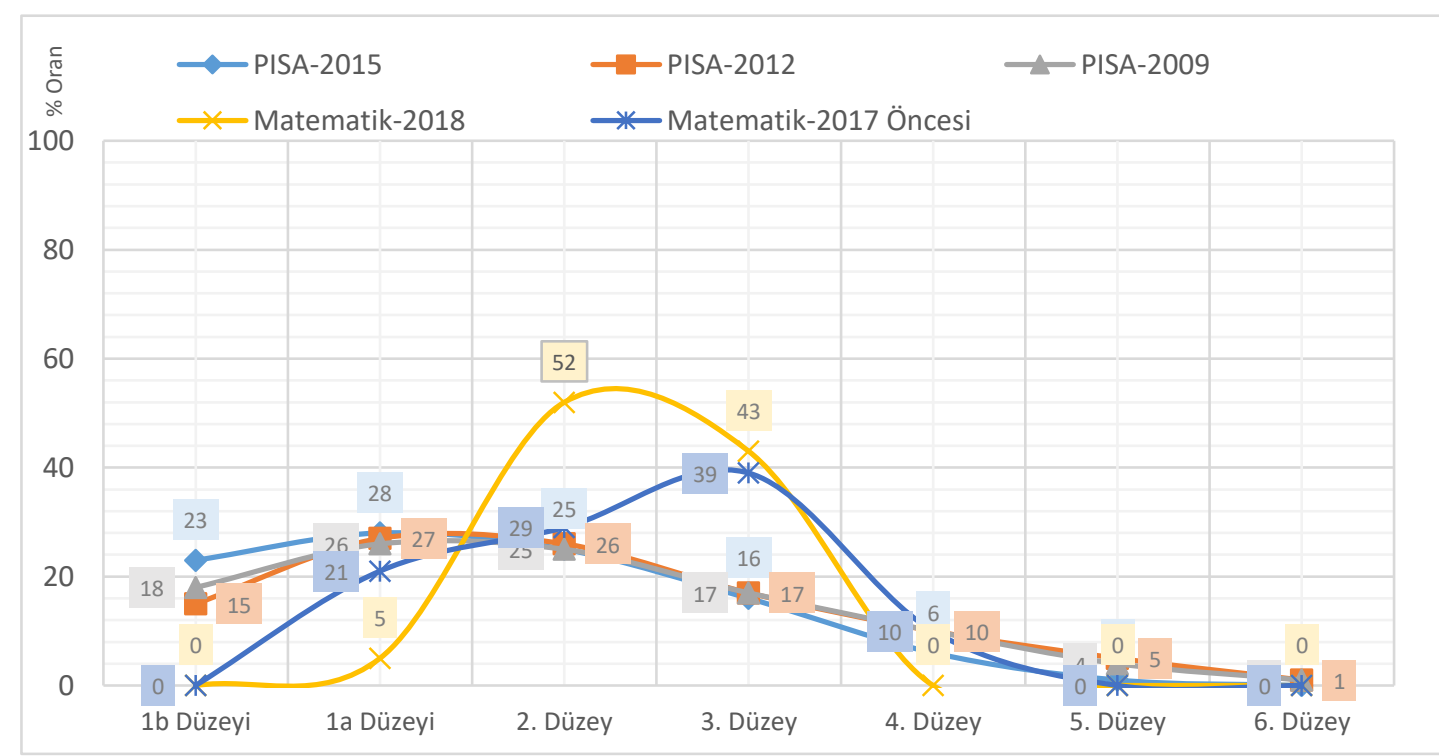

Şekil 4. Türkiye, PISA Matematik Alanı Performansı ve Matematik Dersi Kazanımları İlişkisi

Dil-edebiyat alanı öğretim programı kazanımları ve PISA yeterlikleri

Türk dili ve edebiyatı dersi dokuzuncu sınıf 2103 öğretim programı, iki ayrı ders olup, dil ve anlatım dersi 6 ünite ve 73 kazanım, Türk edebiyatı dersi 4 ünite 123 kazanımdan oluşurken, bu iki dersin üniteler bazında programın .40'1 olarak 4 ünite, kazanımlar bazında programın .27'si olarak 52 kazanım incelenmiştir (İşeri, 2017). 2018'de yürürlüğe giren programda Türk dili ve edebiyatı dersi altında iki ders birleştirilmiş olup, tüm sınıflar için öğretim programı 3 tema ve 95 kazanımdan oluşmaktadır. Güncel programda temalar bazında programın .33 olarak 1 tema; kazanımlar bazında .29'u olarak incelenen 28 kazanıma ilişkin veriler aşağıdaki Tablo-12'de gösterilmiştir. 
Tablo 12.

Türk Edebiyatı Dersi Öğretim Programı İncelenen Temalar ve Kazanımları

\begin{tabular}{|c|c|c|c|c|}
\hline \multicolumn{2}{|c|}{ Tema } & Kazanımlar & Bilgi türü & $\begin{array}{l}\text { Bilişsel } \\
\text { nitelik }\end{array}$ \\
\hline \multirow{28}{*}{ 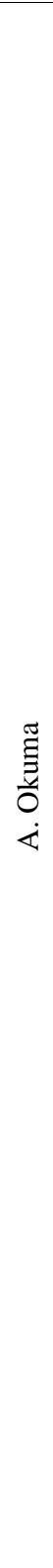 } & \multirow{6}{*}{ A.1. Şiir } & $\begin{array}{l}\text { A.1. 1. Metinde geçen kelime ve kelime gruplarının } \\
\text { anlamlarını tespit eder. }\end{array}$ & Olgusal & Bilme \\
\hline & & A.1. 2. Şiirin temasını belirler. & Üstbilişsel & Analiz \\
\hline & & A.1. 3. Şiirde ahengi sağlayan özellikleri/unsurları belirler & Üstbilişsel & Analiz \\
\hline & & A.1. 4. Şiirin nazım biçimini ve nazım türünü tespit eder & Kavramsal & Kavrama \\
\hline & & $\begin{array}{l}\text { A.1. 5. Şiirdeki mazmun, imge ve edebî sanatları } \\
\text { belirleyerek bunların anlama katkısını değerlendirir. }\end{array}$ & Üstbilişsel & Analiz \\
\hline & & A.1. 13. Metinler arası karşılaştırmalar yapar. & Üstbilişsel & Analiz \\
\hline & \multirow{7}{*}{$\begin{array}{l}\text { A.2. Öyküleyici } \\
\text { Edebi Metinler }\end{array}$} & A.2. 1. Metinde geçen kelime ve kelime gruplarının & Olgusal & Bilme \\
\hline & & $\begin{array}{l}\text { A.2. 2. Metnin türünün ortaya çıkışı ve tarihsel dönem ile } \\
\text { ilişkisini belirler. }\end{array}$ & $\begin{array}{l}\text { Üst } \\
\text { bilişsel }\end{array}$ & Analiz \\
\hline & & A.2. 3. Metnin tema ve konusunu belirler. & & Analiz \\
\hline & & A.2. 4. Metindeki çatışmaları belirler. & $\begin{array}{l}\text { Ustbilişsel } \\
\text { Üsthilissel }\end{array}$ & Analiz \\
\hline & & A.2. 5. Metnin olay örgüsünü belirler. & $\begin{array}{l}\text { Ustbilişsel } \\
\text { Üsthilissel }\end{array}$ & Analiz \\
\hline & & $\begin{array}{l}\text { A.2. 15. Türün ve dönemin/akımın diğer önemli yazarlarını } \\
\text { ve eserlerini sıralar. }\end{array}$ & $\begin{array}{l}\text { Ustbilişsel } \\
\text { Olgusal }\end{array}$ & Bilme \\
\hline & & A.2. 16. Metinlerden hareketle dil bilgisi çalışmaları yapar. & Kavramsal & Uygulama \\
\hline & \multirow{7}{*}{ A.3. Tiyatro } & A.3. 1. Metinde geçen kelime ve kelime gruplarının & Olgusal & Bilme \\
\hline & & $\begin{array}{l}\text { anlamlarını tespit eder. } \\
\text { A.3. } 2 \text {. Metnin türünün ortaya çıkışı ve tarihsel dönemle } \\
\text { ilişkisini belirler. }\end{array}$ & $\begin{array}{l}\text { Üst } \\
\text { bilişsel }\end{array}$ & Analiz \\
\hline & & A.3. 3. Metnin tema ve konusunu belirler. & & Analiz \\
\hline & & A.3. 4. Metindeki çatışmaları belirler. & $\begin{array}{l}\text { Ustbilişsel } \\
\text { Üsthilissel }\end{array}$ & Analiz \\
\hline & & A.3. 5. Metindeki olay örgüsünü belirler & $\begin{array}{l}\text { Ustbillşsel } \\
\text { Üsthilissel }\end{array}$ & Analiz \\
\hline & & $\begin{array}{l}\text { A.3. 13. Türün ve dönemin/akımın diğer önemli yazarlarını } \\
\text { ve eserlerini sıralar. }\end{array}$ & $\begin{array}{l}\text { Ustbillşsel } \\
\text { Olgusal }\end{array}$ & Bilme \\
\hline & & A.3. 14. Metinlerden hareketle dil bilgisi çalışmaları yapar & Kavramsal & Uygulama \\
\hline & \multirow{8}{*}{$\begin{array}{l}\text { A.4.Bilgilendirici } \\
\text { Metinler }\end{array}$} & $\begin{array}{l}\text { A.4. 1. Metinde geçen kelime ve kelime gruplarının } \\
\text { anlamlarını tespit eder }\end{array}$ & Olgusal & Bilme \\
\hline & & $\begin{array}{l}\text { A.4. } 2 \text {. Metnin türünün ortaya çıkışı ve tarihsel dönemle } \\
\text { ilişkisini belirler. }\end{array}$ & Üstbilişsel & Analiz \\
\hline & & $\begin{array}{l}\text { A.4. 3. Metin ile metnin konusu, amacı ve hedef kitlesi } \\
\text { arasında ilişki kurar. }\end{array}$ & Üstbilişsel & Analiz \\
\hline & & A.4. 4. Metnin ana düşüncesi ve yardımcı düşüncelerini & Üstbilişsel & Analiz \\
\hline & & $\begin{array}{l}\text { belirler. } \\
\text { A.4. 5. Metindeki anlatım biçimlerini, düşünceyi }\end{array}$ & Üstbilişsel & Analiz \\
\hline & & geliştirme yollarını ve bunların işlevlerini belirler. & Üstbilişsel & Analiz \\
\hline & & $\begin{array}{l}\text { A.4. 6. Metnin görsel unsurlarla ilişkisini belirler. } \\
\text { A.4. 14. Türün ve dönemin/akımın diğer önemli yazarlarını }\end{array}$ & Olgusal & Bilme \\
\hline & & $\begin{array}{l}\text { ve eserlerini sıralar. } \\
\text { A.4. 15. Metinlerden hareketle dil bilgisi çalışmaları yapar }\end{array}$ & Kavramsal & Kavrama \\
\hline
\end{tabular}

Kaynak: MEB, 2011; MEB, 2018e.

Tablo 12'de verilen Türk dili ve edebiyatı dersi öğretim programı kazanımlarının .29'unu oluşturan okuma temasındaki toplam 28 kazanımın, bilgi içeriği ve bilişsel nitelik boyutuna bakılabilir. Kazanımların; bilgi türü olarak olgusal, kavramsal ve üstbilişsel bilgiyi; bilişsel nitelik olarak bilme, kavrama, uygulama ve analiz düzeyini içeren nitelikleri; "anlamı tespit etme, belirleme, değerlendirme, karşılaştırma, konuyu-ilişkiyi-çatışmayı-olay örgüsünü-işlevlerini belirleme, sıralama, çalışmaları yapma" niteliklerini içermektedir. 
Tablo 13.

İncelenen Türk Dili Ve Edebiyatı Öğretim Programı Kazanımları Kapsam Analizi

\begin{tabular}{llllll}
\hline Bilişsel / Bilgi & $\begin{array}{l}\text { Olgusal } \\
\text { bilgi }\end{array}$ & $\begin{array}{l}\text { Kavramsal } \\
\text { bilgi }\end{array}$ & $\begin{array}{l}\text { İşlemsel } \\
\text { bilgi }\end{array}$ & $\begin{array}{l}\text { Üstbilişsel } \\
\text { bilgi }\end{array}$ & $\begin{array}{l}\text { Topl. } \\
1 \%\end{array}$ \\
\hline & A.1.1- & & & \\
A.2.1- & & & $7 / .25$ \\
Bilme & A.2.15- & & \\
& A.3.1- & & \\
& A.3.13-A.4.1- & & $1 / .03$ \\
\hline Kavrama & A.4.14, & & $3 / .11$ \\
Uygulama & & A.1.4- & & \\
& & A.2.16- & & \\
\end{tabular}

A.1.2-A.1.3-

A.1.5-

A.1.13-A.2.2-

A.2.3

A.2.4-A.2.5-

Analiz

A.3.2-

$17 / .61$

A.3.3-A.3.4-

A.3.5-

A.4.2-A.4.3-

A.4.4-

A.4.5-A.4.6,

Değerlendirme

\begin{tabular}{llllll}
\hline Yaratma & & & \\
\hline Top./Oran & $7 / .25$ & $4 / .14$ & $17 / .61$ & 28 & / \\
\hline
\end{tabular}

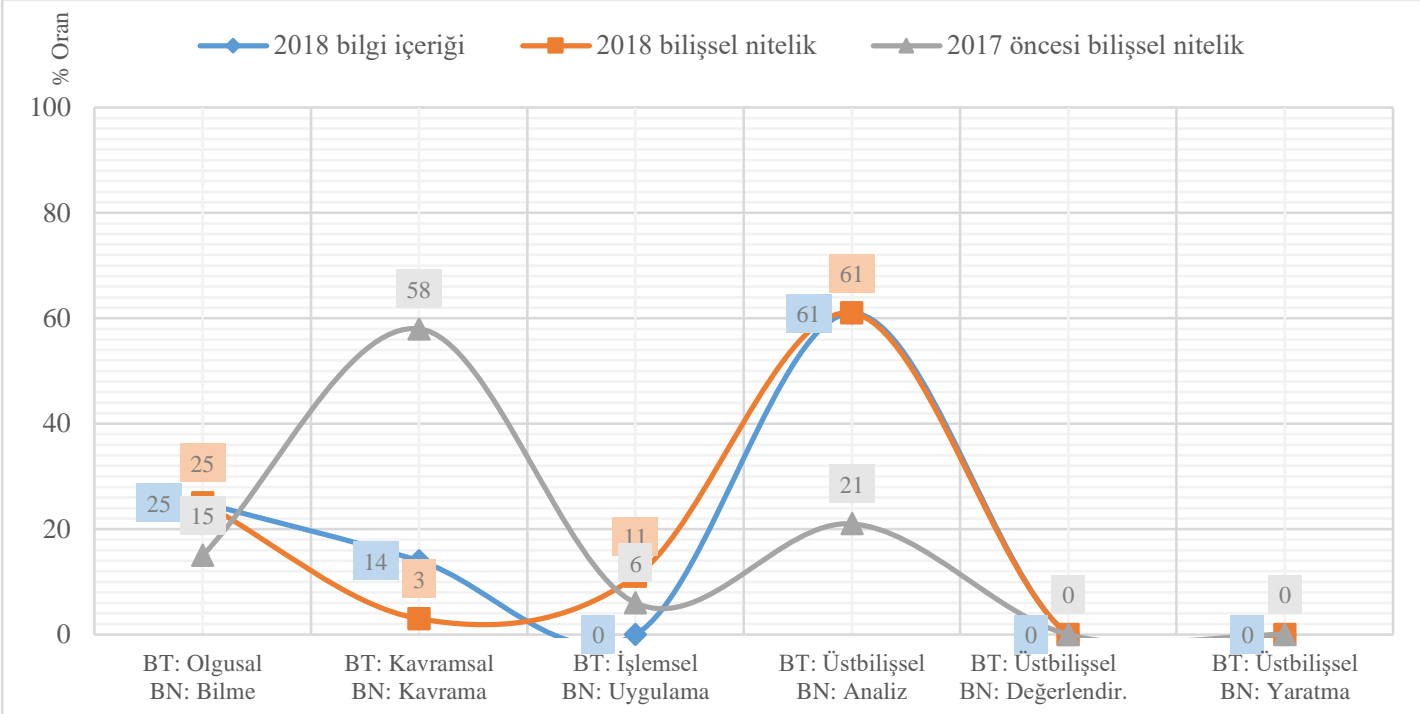

(BT: Bilgi Türü; BN: Bilisssel Nitelik)

Şekil 5. Türk Dili ve Edebiyatı Öğretim Programı Kazanımlarının Kapsam Analizi 
Türk dili ve edebiyatı alanına ilişkin yukarıdaki Tablo 13 ve Şekil 5 birlikte incelendiğinde; Türk dili ve edebiyatı dersi öğretim programları kazanımlarının bireylerde geliștirmeyi öngördüğü nitelik-becerilerin; bilgi türü açısından .25 'i olgusal, .14'ü kavramsal ve .61'i ise üstbilişsel bilgi türlerinde yoğunlaşırken; bilişsel nitelikler boyutunda ise .25 'i bilme, .03'ü kavrama, .11'i uygulama ve .61'inin analiz düzeyinde yoğunlaştığı belirtilebilir. 2011'deki iki dersin öğretim programı kazanımlarına ilişkin incelemede, bilişsel nitelikler boyutunda kazanımların, .15'i bilme, .58'i kavrama, .06's1 uygulama ve .21'i analiz düzeyinde yoğunlaşmıştır (İşeri, 2017). Bu veriler, kazanımların üst düzey bilişsel nitelikler açısından arttı̆̆ını göstermektedir.

Türk dili ve edebiyatı dersi kazanımlarının pısa okuma alanı yeterlik düzeylerine dağılımı: PISA okuma alanı 6 yeterlik düzeyi içerik ve bağlam olarak; metin, okuyucunun metne yaklaşımı ve metnin kullanım amacını içeren üç boyuttan (MEB, 2013d; MEB, 2016) oluşmaktadır. Metin boyutu, metnin sunumu, sınırlılığı, şekli ve türünü içerirken; metnin kullanılış amaç ve durumu boyutu, kişisel, eğitsel, mesleki ve toplumsal bağlamını; okurun metne yaklaşımı boyutu ise; bilgiye ulaşma ve bilgiyi hatırlama, bilgileri bir araya getirme ve yorumlama, kendi düşüncelerini yansıtma ve değerlendirmeyi içermektedir. Bu bağlamda, Türk dili ve edebiyatı öğretim programından incelenen iki ünitedeki 28 kazanımın, PISA okuma alanı yeterlik düzeylerine dağılım oranıyla Türkiye'nin PİSA okuma performansının yeterlik düzeylerine dağılım oranı karşılaştırılabilir.

Tablo 14.

Türk Dili ve Edebiyatı Kazanımlarının PISA Yeterlik Düzeylerine Dağılımı

\begin{tabular}{|c|c|c|c|}
\hline \multicolumn{2}{|r|}{ PISA okuma becerileri yeterlik düzeyleri } & Kazanımlar & Topl. $/ \%$ \\
\hline 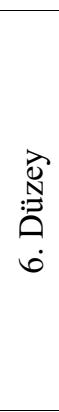 & $\begin{array}{l}\text { Bu düzeyde yer alan öğrenciler, detayll bir şekilde benzerlikleri ve } \\
\text { farklılıkları bulabilir ve çıarımlarda bulunabilir. Metni veya metinleri } \\
\text { ayrıntılarıyla tam olarak anladığını gösterir ve birden fazla metinden elde } \\
\text { ettiği bilgileri bir araya getirebilir. Önemli bilgilerin olduğu metnin } \\
\text { içerisinde açıç̧a ifade edilmemiş kavramlarla başa çıabilir ve soyut } \\
\text { kavramları yorumlayabilir. Birçok kriteri ve görüşü göz önünde } \\
\text { bulundurarak ve metnin ötesinde bir anlayış sergileyerek alışagelmiş } \\
\text { konuları dışındaki metinler üzerinde eleştirel bir değerlendirme } \\
\text { yapabilir ya da hipotezlere ulaşabilir. Metindeki önemsiz detayları fark } \\
\text { edebilir ve analiz edebilir }\end{array}$ & & \\
\hline 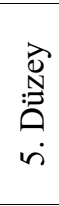 & $\begin{array}{l}\text { Bu düzeydeki öğrenciler, metnin içine yerleştirilmiş bilgileri } \\
\text { belirleyebilme ve gerekli olan bilgilere karar vererek metni } \\
\text { düzenleyebilir. Özel bilgilere dikkat çekerek eleştirel bir değerlendirme } \\
\text { yapabilir ve hipotez kurabilir. Aşina olunmayan bağlamları ayrıntılarıyla } \\
\text { anlayabilir. Beklentilere ters düşen kavramların üstesinden gelebilir }\end{array}$ & & \\
\hline 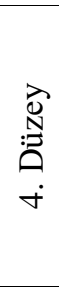 & $\begin{array}{l}\text { Bu düzeydeki öğrenciler, metne yerleştirilmiş bilgileri belirleyebilir ve } \\
\text { gerekli olan bilgilere karar vererek metni düzenleyebilir. Metni bir bütün } \\
\text { olarak ele alarak dil farklılıklarını yorumlayabilir. Metni anlayabilir ve } \\
\text { aşina olmadığı bağlamlara sınıflandırmaları uyarlayabilir. Öğrenciler, } \\
\text { kişisel bilgilerini kullanarak hipotez kurabilme ya da bir metni eleştirel } \\
\text { bir şekilde değerlendirebilir. Alışılmamış uzun/karmaşı metinler } \\
\text { üzerinde derinlemesine bir anlayışa sahip olduğunu gösterir. }\end{array}$ & $\begin{array}{l}\text { A.1.5, } \\
\text { A. } 4.5 \text {, }\end{array}$ & $2 / .07$ \\
\hline
\end{tabular}




\begin{tabular}{|c|c|c|c|}
\hline 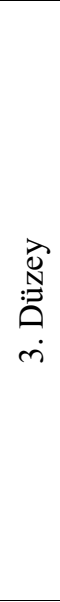 & $\begin{array}{l}\text { Bu düzeydeki öğrenciler, çoklu durumlara karşıllk gelebilecek bilgiler } \\
\text { arasındaki ilişkiyi belirler/ bazı durumlarda bu ilişkiyi tanımlar. Ana fikri } \\
\text { belirlemek, ilişkileri anlamak ve deyimlerin ya da kelimelerin } \\
\text { anlamlarını yorumlamak için metindeki bilgileri bir araya getirebilir. } \\
\text { Öğrencilerin, benzer ve farkl1lıkları bulabilmek ve snıflandıbilmek } \\
\text { için birçok özelliği dikkate almaları gerekmektedir. Genellikle gerekli } \\
\text { bilgi açı olarak verilmemiş olabilir, çok fazla bilgi olabilir ya da } \\
\text { beklentilere ters düşen veya olumsuz bir şekilde belirtilen kavramlar gibi } \\
\text { başka engellerde olabilir. Öğrencilerin metinler arası ilişki kurma, } \\
\text { karşlaştırma yapma, açılama yaparak metinleri irdelemeleri } \\
\text { gerekmektedir ya da metnin özelliklerini yorumlayabilmeleri } \\
\text { gerekmektedir. Öğrenci metni bilinen veya günlük hayatta kullanılan } \\
\text { bilgilerle ilişkilendirerek anladığını gösterir. Öğrenciden metni } \\
\text { ayrıntılarıyla anlaması beklenmez ama asgaride genel ifadeleri anlaması } \\
\text { beklenir. }\end{array}$ & $\begin{array}{l}\text { A.1.2, } \\
\text { A.1.3, } \\
\text { A. } 1.4, \\
\text { A.1.13, } \\
\text { A.2.2, } \\
\text { A. } 2.3, \\
\text { A.2.4, } \\
\text { A. } 2.5, \\
\text { A. } 3.1, \\
\text { A.3.4, } \\
\text { A. } 3.5, \\
\text { A.4.2, } \\
\text { A. } 4.3,\end{array}$ & $13 / .46$ \\
\hline 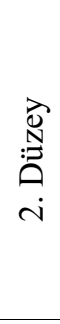 & $\begin{array}{l}\text { Bu düzeydeki öğrenciler, birçok duruma karşı gelebilecek/ çıkarımda } \\
\text { bulunabileceği bir bilgiyi / daha fazla bilgiyi metinde bulabilir. } \\
\text { Metindeki ana düşünceyi belirleyebilir, ilişkileri anlayabilir ya da çok } \\
\text { fazla bilginin olmadığı, fazla çıkarımda bulunulmayacak durumlarda } \\
\text { metnin belli bir bölümünden anlam çıkarır. Metnin bir özelliğine } \\
\text { dayanarak benzer ya da farkl1llkları bulabilir. Kişisel deneyim ya da } \\
\text { tutumlarından yola çıarak metnin dışındaki bilgilerle metnin içindeki } \\
\text { bilgileri karşılaştırabilme, bu bilgiler arasında ilişki kurabilir. }\end{array}$ & $\begin{array}{l}\text { A.3.2, } \\
\text { A.3.3, } \\
\text { A.4. } 4\end{array}$ & $3 / .11$ \\
\hline 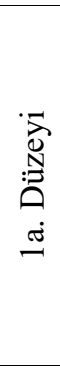 & $\begin{array}{l}\text { Bu düzeydeki öğrenciler, açıkça ifade edilen bir ya da daha fazla } \\
\text { bağımsız bilgiyi metinde bulabilir, aşina olduğu bir konu hakkında } \\
\text { yazılmış bir metnin ana fikrini ve yazarın amaçnı anlayabilir veya } \\
\text { metindeki bir bilgi ile yaygın olarak bilinen günlük bilgi arasında ilişki } \\
\text { kurabilir. Bu düzeydeki öğrencilerin, metinlerde bilgiler açıķa ifade } \\
\text { edilmisstir ve bu metinlerde çok fazla bilgi bulunmamaktadır. Öğrenciler } \\
\text { metindeki ilgili yerlere açı bir şekilde yönlendirilmektedirler. }\end{array}$ & $\begin{array}{l}\text { A.1.1, } \\
\text { A.2.1, } \\
\text { A.2.15, } \\
\text { A.2.16, } \\
\text { A.3.13, } \\
\text { A.3.14, } \\
\text { A.4.1, } \\
\text { A.4.14, } \\
\text { A.4.15, }\end{array}$ & $9 / .32$ \\
\hline 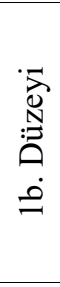 & $\begin{array}{l}\text { Bu düzeydeki öğrenciler, hikaye ya da basit bir liste gibi aşina olduğu bir } \\
\text { bağlam ya da konu hakkında yazllmış kısa, basit bir metninde açıça } \\
\text { ifade edilmiş bir bilgiyi bulabilir. Bu tür metinler genellikle okura } \\
\text { bilginin tekrarlanması, resim ya da benzer sembollerin kullanılması gibi } \\
\text { kanıtlar sunmaktadır. Bu düzeydeki öğrencilerin verilen görevleri yerine } \\
\text { getirebildikleri metinlerde çok fazla bilgi bulunmamakta, okur birbirine } \\
\text { yakın bilgiler arasında basit ilişkiler kurabilir. }\end{array}$ & A.4.6, & $1 / .04$ \\
\hline & Toplam & & $28 / .100$ \\
\hline
\end{tabular}

Kaynak: OECD, 2014, 2016b; MEB, 2010a-b, 2015, 2016.

Tablo 14 incelendiğinde, Türk dili ve edebiyatı dokuzuncu sınıf öğretim programı kazanımlarının, PISA yeterlik düzeylerine dağılımında kazanımların; .36'sının alt yeterlik düzeylerine, .11'inin temel asgari yeterlikleri içeren ikinci düzeye, .53'ünün ise üçüncü düzey ve üstündeki yeterlik düzeylerine yoğunlaştı̆̆ belirtilebilir. Bu veriler, 2011'deki dil ve anlatım, Türk dili ve edebiyatı dersleri öğretim programları kazanımlarının yeterlik düzeylerine dağılımı oranıyla karşılaştırıldığında, önceki programlarda kazanımların; .33'ünün alt yeterlik düzeylerine, .42 'sinin temel asgari yeterlikleri içeren ikinci düzeye, .25'inin üçüncü düzey ve üstündeki yeterlik düzeylerine yoğunlaştı̆̆ programı kazanımlarının, alt yeterlik düzeylerindeki oranı, .03 artarken, temel asgari yeterlikleri içeren ikinci düzeydeki kazanımların .31 düştüğü, üçüncü düzey ve üstündeki düzeylerde kazanımların ise .28 arttığı belirtilebilir. Bu durumda Türk dili ve edebiyatı kazanımlarının PISA yeterlik düzeylerine dağılımıyla Türkiye'nin PISA okuma performansının yeterlik düzeylerine dağılımı oranları karşılaştırılabilir. 


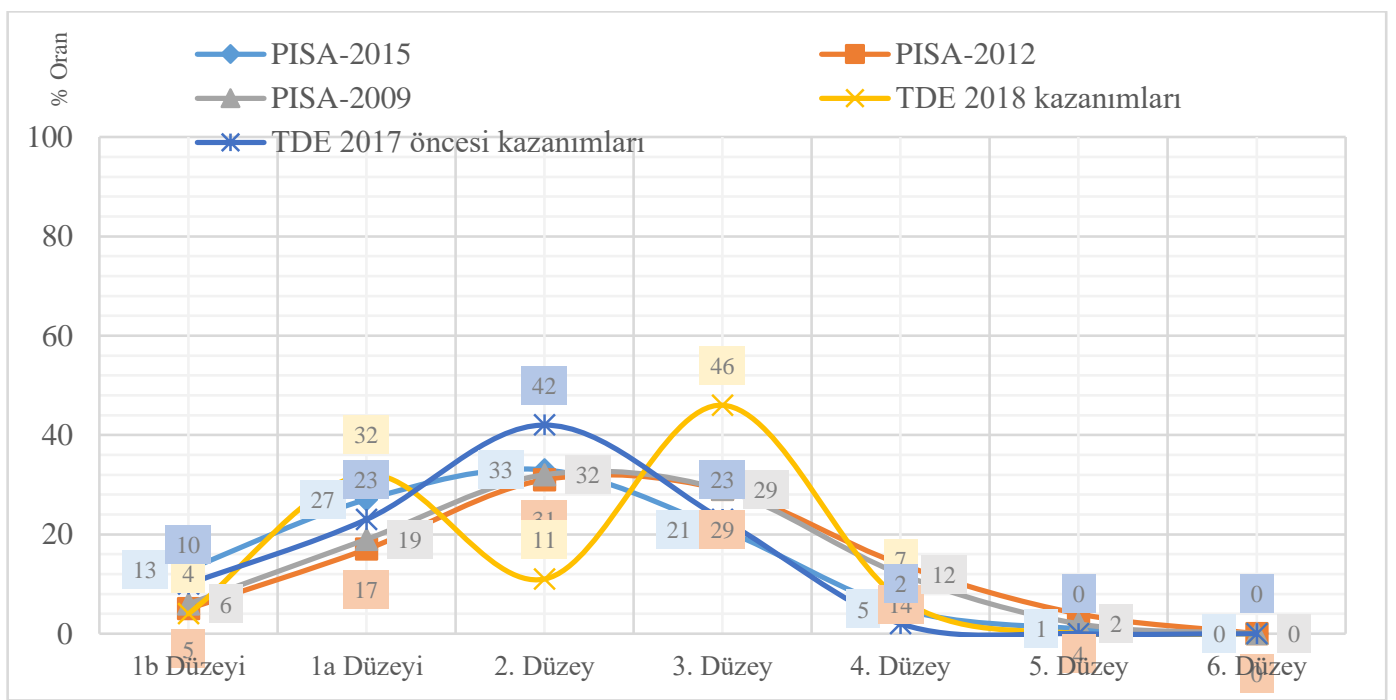

Şekil 6. Türkiye, PISA okuma alanı performansı, Türk dili ve edebiyatı dersi kazanımları ilişkisi

Yukarıdaki Şekil 6 incelendiğinde, 2011 öğretim programları (dil ve anlatım, Türk dili ve edebiyatı) kazanımlarının (İşeri, 2017), PISA yeterlik düzeylerine dağılımı oranı ile Türkiye'nin PISA okuma alanı performansının yoğunlaştığı alt, iki ve üçüncü yeterlik düzeylerine dağılım oranların örtüşmektedir. 2018' de yürürlüğe giren öğretim programında ise kazanımlar en fazla üçüncü yeterlik düzeyinde yoğunlaşırken; buna bağlı alt, iki, dört ve beşinci yeterlik düzeylerinde de dağılımı söz konusudur. Bu durum, üst yeterlik düzeylerine doğru çıkıldıkça hem kazanım hem de öğrenci performansının yokluğu, kazanımların bilgi türü ve bilişsel nitelikleriyle açıklanabilir.

Türkiye ortaöğretim kademesinden incelenen dokuzuncu sınıf öğretim programları kazanımlarının, bilgi türü ve bilişsel nitelikler açısından ilgili disiplin alanlarının bilgi yapılarına bağımlı olduğu, bilgi yapıları üzerinden farklı ilişkisel bağlamların üretimini sağlayan üst bilişsel beceri ve niteliklerin sınırlı olduğu belirtilebilir. Bu durum, kazanımların, bilgi türü ve bilişsel nitelikler bağlamında yoğunlaştıkları PISA yeterlik düzeyleri ile Türkiye'nin farklı alanlardaki PISA performansının yoğunlaştığ1 yeterlik düzeylerinin ilişkisel karşılaştırmada örtüştügüu, bu örtüşmede özellikle kazanımların bulunmadığı yeterlik düzeylerinde, öğrenci performansının da bulunmaması durumu, örtüșmenin diğer bir boyutu olarak okunabildiği gibi kazanımlar ve yeterlikler arası tutarlılığın önemini de ortaya koymaktadır. Bu duruma bağlı olarak 2018-19 öğretim yılında yürürlüğe girecek olan ilgili öğretim programları kazanımlarının, küresel yeterlikler olan PISA yeterlikleri, Türkiye kalkınma planları ve milli eğitim bakanlığı strateji belgelerinin öngörüleriyle örtüşmediği sonuçları ortaya çıkmaktadır.

\section{Tartışma ve Sonuç}

Türkiye ortaöğretim dokuzuncu sınıf öğretim programları kazanımları, PISA araştırmaları yeterlik düzeyleri ve Türkiye'nin PISA performansı arasındaki ilişki farklı boyutlarda bütünsel olarak irdelenebilir.

PISA performansıyla ülkelerin program politikaları karşılaştıııldığında, Amerika'nın PISA'daki performansını irdeleyen Eisner (2016) ve Zhao (2016), Amerika'daki sürekli standartlaştırma ve homojenleştirmeyi öngören "Geride Hiçbir Çocuk Kalmasın" ile "Ortak Çekirdek Standartları Girişimi”" gibi politikaların eğitim programlarını daralttığı, sınav odaklı öğretime yönelttiği, standartlaştırılmış sınavların, çocukların eğitimsel deneyimlerini sınırlama, ilgi alanlarını ve tutkularını keşfetme firsatlarından yoksun bıraktığını belirtir. Buna bağlı olarak PISA'da yüksek başarı yakalayan ülkelere ilişkin analizleri inceleyen Hammond ve McCloskey (2016), farklı ülkelerde farklı sınıf düzeylerinde öğretilen konulara bakıldığında, başarısı yüksek ülkelerin her yıl daha az konuyu daha derinlikli öğrettiğini, önemsiz konulardan ziyade akıl yürütme becerileri ve bilginin kullanılmasına daha fazla odaklandıkları, alanlar içinde ve arasında 
daha dikkatli bir sıra takip edildiğini belirtmektedirler. Kalkan (2008) ise, PISA matematik, okuma ve fen alanında en başarılı kümeyi oluşturan (Finlandiya, Hong Kong, Kore, Japonya) ülkelerin ortak özelliğinin bilgi temelli ekonomiye dayalı müfredat değişikliklerini tamamlamış olduklarını (akt. Acar, 2012) belirtir. Bu veriler, öğretim programları ve kazanımlarının, belirli bilgi yapılarına bağımlılığını değil, bilgi yapıları üzerinden farklı ilişkisel bağlamların üretimini sağlayan bilişssel boyutun önemini ortaya koymaktadır.

PISA yeterlilikleri bağlamında Türkiye'de yürütülen farklı kapsamdaki araştırmalara bakıldığında, program ve yeterlikler ilişkisine yönelik araştırmalarda; Batur ve Alevli (2014); Batur ve Ulutaş (2013) ilköğretim Türkçe dersi okuma ve anlama becerileri kazanımlarının, PISA alt düzey yeterlilikleriyle örtüşürken, beş ve altıncı düzeyde doğrudan örtüşebilen kazanımların bulunmadığı, bunun Türkiye'nin PISA'daki düşük performansının temel nedeni olduğu belirtilir. Demiral ve Menşan (2017) sekizinci sınıf Türkçe dersi okuma becerilerini kazanımlarının çoğunluğunun uygulama ve analiz düzeylerinde yoğunlaştığı, üst düzey bilişsel niteliklerde kazanımların bulunmadığı belirlenmiştir. Diker Coşkun (2013) İlköğretim ikinci kademe Türkçe ders kitaplarında yer alan metin çeşitliliğinin uluslararası ölçütler açısından okuma becerisini geliştirme ve farklı alanlara aktarma konusunda yetersiz olup, alt okuma düzeyinde kaldığını belirtmektedir. Sınav içerikleri ve yeterlikler ilişkisine yönelik araştırmalarda ise; İskenderoğlu, Erkan ve Serbest (2013) sekizinci sınıf seviye belirleme sinavlarındaki matematik sorularının PISA matematik yeterlik düzeylerine dağılımında, soruların; dördüncü düzeye kadar çıkabildiği, en fazla ise iki ve üçüncü düzeylerde soruların yoğunlaştığı belirtilmektedir. İncikabı, Pektaş ve Süle, (2016), Türkiye'de ortaöğretime geçiş sınavlarında, üst bilişsel süreçlere yer verilmediği, bu durumun ulusal matematik ve fen öğretim programlarında öngörülen süreç becerileriyle örtüşmediği; İncikabi $(2011,2012)$ Türkiye'de ortaöğretim ve yükseköğretim seviyelerinde uygulanmakta olan sınavlar ve içeriklerinin hem ilgili müfredatla hem de uluslararası eşdeğer sınavlarla örtüşmediği (akt. İncikabı, Pektaş ve Süle, 2016) belirtilmektedir. Bu veriler araştırmada ulaşılan sonuçlarla benzerlik gösterdiği gibi, Türkiye'deki farklı öğretim kademelerindeki öğretim programlarının uluslararası nitelik ve eşdeğerde bir içeriğe sahip olmadı $\breve{~} 1$ da belirtilebilir.

PISA performansına etki eden ülkelerin sosyal gerçekliği ve kazanımlar ilişkisine bakıldığında, Türkiye'deki 15 yaş grubu öğrencilerinin düşük PISA performansının, düşük sosyoekonomik yapıyla ilişkisinin .69 olduğu, ailelerin sosyoekonomik yapısının, öğrenciler arasında akademik başarı farkı ve eşitsizliklerinin büyük bir kısmının temel faktörü olduğu, farklı türdeki okullar arasındaki kalite farkının, öğrenciler arasında yaşam boyu eşitsizliğe yol açtığı (Dünya Bankas1, 2011; OECD, 2013a,b; TEDMEM, 2015; MEB, 2013d, 2016) bu gibi durumlar, kazanımların sosyo-ekonomik etki değeri ve sosyal içerme niteliğini de sorgulamayı gerekli k1lmaktadır.

Eğitimin, içerik, niteliğinde belirleyici olan kazanım-yeterliklerin odağı, eğitim pratiğini belirli standartlara bağımlı kılmakla birlikte, eğitimin nitelik ve odağını da belirlemektedir. Bu perspektif derinleştirilecek olunursa Morin (2003) eğitimin, bilgileri birbirinden ayırma, bölümleme ve yalıtmayı öngörmesiyle bilişsel olarak mekanist, indirgeyici ve tek boyutlu düşünmeyi ürettiği; Kuhn ise, varolan bilginin aktarımını öngören ders kitabı eğitiminin, tek bir geleneğin, belirli bir algılama ve bilimi uygulama tarzına bağlılığı aşılamayı esas aldığını (Kuhn, 1963, akt. Barnes, 2008) belirten bu iki yaklaşımın bütünsel anlamıyla Türkiye'deki kazanımlara bakıldığında İşeri (2014), Türkiye'de, program geliştirme süreçlerine ilişkin, tüm okul türkademeleri, disiplin alanları ve sosyo-kültürel yapılar için aynı öğretim programları ve içeriklerinin öngörüldüğü; bilginin, bireysel, sosyo-kültürel farkl1lıklar-ihtiyaçlar ve pratik yaşam bağlamında deneyimlenebilir bir yapı olmaktan soyutlanarak, belirli disiplin alanları içeriklerine bağlı belirli bilişsel niteliklerle sınırlı olduğu sonuçlarıyla araştırmada ortaya konulan sonuç verileriyle örtüşmektedir. Bu açıdan kazanım-yeterliklerin, belirli disiplin alanlarının bilgi yapısı ve içeriğinin aktarımına bireyi hapsetmek yerine, bireyin kendisini bulmasını, hayatının anlamını keşfetmesini, kendine ulaşma ve özgürleşme bilincine katk1 sağlama motivasyonu, bireyi her alanda başarılı kılacağı belirtilebilir. Aksi takdirde kazanım-yeterlikler sistem ve yapıların mekanik yeniden üretiminden öteye gidemez. 


\section{Kaynaklar}

Acar, T. (2012). Türkiye'nin PISA 2009 sonuçlarına göre OECD'ye üye ve aday ülkeler arasındaki yeri. Kuram ve Uygulamada Ĕgitim Bilimleri, 12(4), 2561-2572.

Akar, H. (2016). Durum çalışması. A. Saban ve A. Ersoy (Yay. haz.). Eğitimde Nitel Araştırma Desenleri içinde (ss. 111-148). Ankara: Anı Yayıncılık.

Akturan, U. ve diğerleri (2008). Doküman incelemesi. T. Baş ve U. Akturan (Yay. haz.), Nitel Araştırma Yöntemleri Nvivo 7.0 ile Nitel Veri Analizi içinde (ss. 117-123). Ankara: Seçkin Yayınları.

Akturan, U. ve diğerleri (2008). Söylem analizi. T. Baş ve U. Akturan (Yay. haz.), Nitel Araştırma Yöntemleri Nvivo 7.0 ile Nitel Veri Analizi, içinde (ss. 25-36). Ankara: Seçkin Yayınları.

Anagün, Ş. S. (2011). PISA 2006 sonuçlarına göre öğretme-öğrenme süreci değişkenlerinin öğrencilerin fen okuryazarlıklarına etkisi. Eğitim ve Bilim, 36(162), 84-102.

Anderson, L. W. ve Krathwohl, D. R. (Ed.). (2014). Öğrenme ögretim ve değerlendirme ile ilgili bir sınıflama D. Ali Özçelik (Çev.). Ankara: Pegem Akademi.

Anıl, D. (2009). Uluslararası Öğrenci Başarılarını Değerlendirme Programı'nda (PISA) Türkiye'deki öğrencilerin fen bilimleri başarılarını etkileyen faktörler. Eğitim ve Bilim, 34(152), 87-100.

Aydın, A., Sarıer, Y. ve Uysal, Ş. (2012). Sosyoekonomik ve sosyokültürel değişkenler açısından PISA matematik sonuçlarının karşılaştırılması. Eğitim ve Bilim, 37(164), 20-30

Barnes, B. (2008). T. S. Kuhn ve sosyal bilimler. H. Arslan (Çev.). İstanbul: Paradigma Yayınları.

Baş, T. (2008). Araştırma süreci. T. Baş ve U. Akturan (Yay. haz.). Nitel Araştırma Yöntemleri Nvivo 7.0 ile Nitel Veri Analizi içinde (ss. 9-19). Ankara: Seçkin Yayınları.

Batur, Z. ve Alevli, O. (2014). Okuma becerileri dersinin PISA okuduğunu anlama yeterlilikleri açısından incelenmesi. Okuma Yazma Ĕ̈itimi Araştırmaları, 2(1), 22-30.

Batur, Z. ve Ulutaş, M. (2013). PISA ile Türkçe öğretim programındaki, okuduğunu anlama kazanımlarının örtüşme düzeylerinin incelenmesi. The Journal of Academic Social Science Studies, 6(2), 1549-1563.

Benton, J. (2007). Küreselleşme ve kendini yönetme hakkı: Eğitimsel bakış açıları. H. Hüseyin Aksoy (çev.). E. Oğuz, A. ve Yakar (Yay. haz.), Küreselleşme ve Eğitim içinde (ss. 119140). Ankara: Dipnot Yayınları.

Bilgin, N. (2006). Sosyal bilimlerde içerik analizi teknikler ve örnek çalı̧̧malar. Ankara: Siyasal Kitabevi.

Demiral, H. ve Menşan, Ö. H. (2017). Sekizinci sınıf Türkçe dersinin PISA okuma becerilerine göre değerlendirilmesi. Küreselleşen Dünyada Eğitim, içinde (ss. 567-580). Pegem Yayınları.

Devlet Planlama Teşkilatı-DPT. (2006). Dokuzuncu kalkınma planı (2007-2013).

Devlet Planlama Teşkilatı-DPT. (2013). Onuncu kalkınma planı (2014-2018).

Diker, Coşkun, Y. (2013). Türkçe ders kitaplarının PISA sınavı okuma ölçütleri açısından incelenmesi. Mehmet Akif Ersoy Üniversitesi Eğitim Fakültesi Dergisi, 13( 26), 22-43.

Dünya Bankas1. (2011). Türkiye'de temel eğitimde kalite ve eşitliğin geliştirilmesi zorluklar ve seçenekler. Dünya Bankası İnsani Kalkınma Departmanı Avrupa ve Orta Asya Bölgesi.

Dünya Bankas1. (2014). Türkiye'nin deneyimleri: Entegrasyon, kapsama, kurumlar (Resmi olmayan çeviri).

Eisner, E. W. (2016). Bir okulun işini iyi yapıyor olması ne anlama gelir? Ornstein ve diğerleri. (Yay. haz.), Nilay T. Bümen (Çev. edt.). Eğitim Programlarında Güncel Sorunlar içinde (ss. 21-29). Ankara: Pegem Akademi Yayınları.

ERG. (2016). Eğitim izleme raporu 2015-16. Eğitim Reformu Girişimi.

Eurydice. (2002). Key Competencies a developing concept in general compulsory education. Erişim adresi: eacea.ec.europa.eu/education/eurydice/documents/all_publications. pdf

Gökçe, O. (2006). Içerik analizi kuramsal ve pratik bilgiler. Ankara: Siyasal Kitabevi

Hammond, L. D. ve McCloskey (2016). Dünya genelinde öğrenme için değerlendirme: Uluslararası (düzeyde) rakip olmak ne anlama geliyor? Ornstein ve diğerleri (Yay. haz), 
Nilay T. Bümen (Çev. edt.). Eğitim Programlarında Güncel Sorunlar içinde (ss. 311322). Ankara: Pegem Akademi Yayınları.

Hesapçıŏlu, M. (2010). Postmodern/ küresel toplumda eğitim, okul ve insan hakları. O. Oguz, vd. (Ed.) içinde, 21. Yüzyılda Eğitim ve Türk Eğitim Sistemi içinde (ss. 21-56). Ankara: Pegem Akademi.

İncikabı, L., Pektaş, M. ve Süle, C. (2016). Ortaöğretime geçiş sınavlarındaki matematik ve fen sorularının PISA problem çözme çerçevesine göre incelenmesi. Ahi Evran Üniversitesi Kırşsehir Ĕ̈itim Fakültesi Dergisi (KEFAD), 17(2), 649-662.

İskenderoğlu, T. A., Erkan, İ. ve Serbest, A. (2013). 2008-2013 yılları arasındaki SBS matematik sorularının PISA matematik yeterlik düzeylerine göre sinıflandırılması. Turkish Journal of Computer and Mathematics Education, 4(2), 147-168.

İşeri, A. (2014). Türkiye'de uygulanan program geliştirme modellerinin pragmatist felsefe açısından epistemoloji sorunu. IOJES: International Online Journal of Education Sciences, 6(1), 214-230. doi: /10.15345/iojes.2014.01.018.

İşeri, A. (2017). PISA yeterlik düzeyleri ve Türkiye öğretim programları kazanımları karş1laştırması. IV. International Eurasian Educational Research Congress, 2017 Conference Proceedings. Pamukkale University / Denizli.

Kalkınma Bakanlığı. (2014). 2014-2018, X. kalkınma planı eğitim sisteminin kalitesinin artırllması özel ihtisas komisyonu raporu. Ankara.

Karasar, N. (2005). Bilimsel araştırma yöntemi (15.bask1). Ankara: Nobel Yayınları.

Milli Eğitim Bakanlığı. (2005). PISA 2003 projesi ulusal nihai rapor. Ankara: Eğitim Araştırma ve Geliştirme Dairesi Başkanlığı. Erişim adresi: ttkb.meb.gov.tr/

Milli Eğitim Bakanlığı. (2010a). PISA 2006 projesi ulusal nihai rapor. Ankara: Eğitim Araştırma ve Geliştirme Dairesi Başkanlığı. Erişim adresi: ttkb.meb.gov.tr/

Milli Eğitim Bakanlığı. (2010b). Uluslararası ögrenci değerlendirme programı, PISA 2009 ulusal ön raporu. Ankara: Eğitim Araştırma ve Geliştirme Dairesi Başkanlığı. Erişim adresi: ttkb.meb.gov.tr/

Millî Eğitim Bakanlığı. (2011). Dil ve anlatım dersi (9-12. Sinıflar) öğretim programı. Ankara: Talim ve Terbiye Kurulu Başkanlığı. Erişim adresi: ttkb.meb.gov.tr/

Millî Eğitim Bakanlığı. (2013a). Ortaöğretim fizik dersi (9-12. sinıflar) öğretim programı. Ankara: Talim ve Terbiye Kurulu Başkanlığı. Erişim adresi: ttkb.meb.gov.tr/

Millî Eğitim Bakanlı̆̆ı. (2013b). Ortaöğretim kimya dersi ögretim programı (9-12. sinıflar). Ankara: Talim ve Terbiye Kurulu Başkanlığı Erişim adresi: ttkb.meb.gov.tr/

Millî Eğitim Bakanlığı. (2013c). Ortaöğretim matematik dersi öğretim programı (9-12. sinıflar). Ankara: Talim ve Terbiye Kurulu Başkanlığı Erişim adresi: ttkb.meb.gov.tr/

Millî Eğitim Bakanlığı. (2013d). PISA uluslararası ögrenci değerlendirme programı, PISA 2012 ulusal ön raporu. Ankara: Yenilik ve Eğitim Teknolojileri Genel Müdürlüğü. Erişim adresi: ttkb.meb.gov.tr/

Milli Eğitim Bakanlığı. (2013e). Ortaöğretim biyoloji dersi (9-12. Sinıflar) öğretim programı. Talim Terbiye Kurulu Başkanlığı, 19.01.2018 tarih ve 34 sayılı kararı. Erişim adresi: ttkb.meb.gov.tr/

Millî Eğitim Bakanlığı. (2015). PISA 2012 araştırması ulusal nihai rapor. Ankara: Ölçme, Değerlendirme ve Sinav Hizmetleri Genel Müdürlüğü. Erişim adresi: ttkb.meb.gov.tr/

Millî Eğitim Bakanlığı. (2016). Uluslararası öğrenci değerlendirme programı PISA 2015 ulusal raporu. Ankara: Ölçme, Değerlendirme ve Sinav Hizmetleri Genel Müdürlügü. Erişim adresi: ttkb.meb.gov.tr/

Milli Eğitim Bakanlı̆̆ı. (2018a). Ortaöğretim biyoloji dersi (9-12. Sinıflar) öğretim programı. Talim Terbiye Kurulu Başkanlığı, 19.01.2018 tarih ve 34 sayılı kararı. Erişim adresi: ttkb.meb.gov.tr/

Milli Eğitim Bakanlığı. (2018b). Ortaöğretim fizik dersi (9-12. Sinıflar) ögrretim programı. Talim Terbiye Kurulu Başkanlığı, 19.01.2018 tarih ve 28 sayılı kararı, Erişim adresi: ttkb.meb.gov.tr/ 
Milli Eğitim Bakanlığı. (2018c). Ortaöğretim kimya dersi (9-12. Sinıflar) öğretim programı. Talim Terbiye Kurulu Başkanlığı, 19.01.2018 tarih ve 30 sayılı kararı, Erişim adresi: ttkb.meb.gov.tr/

Milli Eğitim Bakanlığı. (2018d). Ortaöğretim matematik dersi (9-12. Sinıflar) öğretim programı. Talim Terbiye Kurulu Başkanlığı, 19.01.2018 tarih ve 32 sayılı kararı. Erişim adresi: ttkb.meb.gov.tr/

Milli Eğitim Bakanlığı. (2018e ). Ortaögretim Türk dili ve edebiyatı dersi (9-12. Sinıflar) ögretim programı. Talim Terbiye Kurulu Başkanlığı, 19.01.2018 tarih ve 39 sayılı kararı, Erişim adresi: ttkb.meb.gov.tr/erişim

Morin, E. (2003). Geleceğin ĕgitimi için gerekli yedi bilgi. H. Dilli (Çev.): İstanbul Bilgi Üniversitesi Yayınları.

OECD (2016b). PISA 2015 Results (Volume I): Excellence and Equity in Education, PISA. OECD Publishing, Paris. doi./10.1787/9789264266490-en

OECD. (2009). PISA 2009 assessment framework - key competencies in reading, mathematics and science. Erişim adresi: oecd.org/pisa/pisaproducts/44455820.pdf

OECD. (2010). PISA 2009 at a glance. OECD publishing. doi./10.1787/9789264095298-en

OECD. (2012). Education today 2013: The OECD perspective. OECD publishing. Erişim adresi: dx.doi.org/10.1787/edu_today-2013-en

OECD. (2013a). Eğitim politikasl genel görünümü: Türkiye. Eğitim ve Beceriler Müdürlüğü, Eğitim Politikası Genel Görünümü. oecd.org/edu/policyoutlook.htm.

OECD. (2013b). PISA 2012 results in focus what 15-year-olds know and what they can do with what they know. Erişim adresi: oecd.org/pisa.

OECD. (2014). PISA 2012 results: what students know and can do-student performance in mathematics, reading and science (volume-1, revised edition, february 2014), PISA. OECD Publishing. doi. /10.1787/9789264201118-en

OECD. (2016a). PISA 2015 Assessment and Analytical Framework: Science, Reading, Mathematic and Financial Literacy. PISA, OECD Publishing, Paris.

Oktay, A. (2010). 21. Yüzyllda yeni eğilimler ve eğitim. O. Oğuz ve diğerleri (Yay. haz.). 21. Yüzyılda Eğitim ve Türk Eğitim Sistemi içinde (ss. 1-19). Ankara: Pegem Akademi Yayınlar1.

Robson, C. (2015). Bilimsel araştırma yöntemleri gerçek dünya araştırması Ş. Çınkır ve N. Demirkasımoğlu (Çev.). Ankara: Anı Yayıncılık.

Sayıhan, F. (2007). Küreselleşme ve eğitimdeki değişim. E. Oğuz ve A. Yakar (Yay. haz.), Küreselleşme ve Eğitim içinde (ss. 59-82). Ankara: Dipnot Yayınları.

Scott, D. ve Morrison, M. (2016). Eğitim araştırmasında temel fikirler ve kavramlar Ü. Tatlıcan (Çev.). Ankara: Sentez Yayıncıllk.

TEDMEM. (2015). 2015 eğitim değerlendirme raporu. Ankara: Türk Eğitim Derneği Yayınları.

Zhao, Y. (2016). Yenilik ve yaratıcılıkta sınıfta kalmak. Ornstein ve diğerleri (Yay. haz.), Nilay T. Bümen (Çev. edt.). Eğitim Programlarında Güncel Sorunlar içinde (ss. 189-196). Ankara: Pegem Akademi Yayınları.

\section{Extended Abstract \\ Introduction}

The research includes the examination of the effect of PISA researches which are a means to determine the quality and performance of education policies on a global scale to content-quality of the training in Turkey within the context of its effect to the national education policies. In this regard, determination of the education qualities of learning outcomes of the curricula in Turkey, information structure and cognitive qualities as content on a global scale related to the levels of PISA competence is an important issue. Therefore, the PISA performance in the last five periods in the context of global competencies of the students at 15 age group in Turkey makes the contentquality of education searchable with regards to many factors. Key element playing a role in the curricula in Turkey, contents of textbooks, education practices, development and evaluation of the contents is curriculum in current program development theory and its learning outcomes. This 
determinant effect of learning outcomes of curricula in Turkey makes it necessary to examine the relationship of information structure and cognitive qualities of learning outcomes as content with the levels of PISA competence. For this reason, in this research, an answer had been searched for the question of: What is the distribution status of the learning outcomes of the curricula developed in two different periods within the scope of Turkish secondary education level 9th grade science, math and Turkish language and literature classes directly related to the content of PISA researched, and the relationship of this distribution status with the PISA performance of Turkey in different periods? The answer of this question is important in terms of the determination of international validity qualities of centralized curricula and education policies in Turkey.

\section{Method}

The research includes the universe of the study based on the learning outcomes of curricula of Turkish secondary education level ninth grade science, math and linguistic sciences classes directly related to the scope of the PISA researches' levels of competence in science, math and reading fields. The research is a qualitative study based on descriptive survey models and had been carried out based on a single-integrated case study and relational case study within the scope of case study from qualitative research design in thoroughly evaluation of data on two different fields. The research data had been collected from two different sources; in first data source, data related to the scope and quality of levels of competence examining the national and international reports of PISA researches comparatively had been collected. In second data source, the scope and learning outcomes of two for each units from the curricula of science fields (biology, physics, chemistry), math, Turkish language and literature classes for ninth grade developed in two different periods (2011-2013 educational year and 2017-18 educational year) by the Ministry of National Education towards the examination of learning outcomes of the curricula in Turkey had been examined. In the analysis of research data, "content and discourse analysis" had been applied; and frequency analyzes and charts coded by examining the learning outcomes of curricula for Turkish secondary education ninth grade on content analysis, and content, structure and contexts of the levels of PISA competence in three different fields in terms of information structures (factual, conceptual, operational, metacognitive) and cognitive processes (knowing, comprehension, application, analysis, evaluation, creation) in the taxonomy of Anderson and Krathwool were created. In discourse analysis, content structure and meaning of the learning outcomes of curricula and levels of competence of PISA researches as the processes of discourse analysis; had been examined based on the processes of reading data, classification, interpretation, being signified, configuration and macro configuration. In the validity of the research data, analysis categories had been determined and applied, two different data source and two different data analysis method had been applied within the scope of structural validity; in internal validity, credibility based on causality of data, and in external validity, transmissibility with analytical generalizations with reference to the relationship between two cases had been grounded on. Within the scope of reliability, consistency by using analysis units for the data analysis in internal reliability; opinions of a branch teacher for each examination and coding of the learning outcomes of different curricula, and expert academician for comparison, consensus-oriented consistency, confirmability were based on in external reliability.

\section{Findings and Discussion}

Secondary education ninth class in Turkey; had been examined under science (biology, physics and chemistry) classes, math class and Turkish language and literature class in terms of the learning outcomes, information content and cognitive qualities of each field in research findings related to the distribution status of learning outcomes of secondary education ninth grade curricula in Turkey to the levels of competence of PISA researches. The learning outcomes of the curricula examined in each field had been compared by the levels of PISA competence and the PISA performance of Turkey in different periods. Based on these data, it can be stated that the learning outcomes of the ninth grade curricula examined in the secondary education level in Turkey is dependent on the information structure of disciplinary fields related in terms of the type of 
information and cognitive qualities, and metacognitive skills and qualities which provide the production of different relational context through information structures. This situation shows the importance of consistency between learning outcomes and competencies such as the fact that the learning outcomes match up with the levels of PISA competence that they concentrate within the context of information structure and cognitive qualities, and the case of absence of student performance in this overlap especially in levels of competence without learning outcomes can be read as another dimension of this overlap. Therefore, in this research, it can be stated that curricula in different training levels in Turkey do not have an international quality and equivalent content. In this regard, the results that the learning outcomes of the related curricula to be effected in 201819 school year, development plans and strategy documents of the Ministry of National Education do not match up with the predictions related to the current period, and therefore, are insufficient in terms of global competencies with regards to the PISA competencies have come out. In this respect, it can be stated that learning outcomes-competencies are the motivation of the individual to find himself, to discover the meaning of his life, to achieve self-awareness and to contribute to the awareness of liberation rather than imprisoning the individual to the transfer of information structure and content of particular disciplinary fields, will make the individual successful in all areas. 